\title{
WHAT THE Right OF PUBLICITY CAN LEARN FROM TRADEMARK LAW
}

\author{
Stacey L. Dogan* and Mark A. Lemley**
}

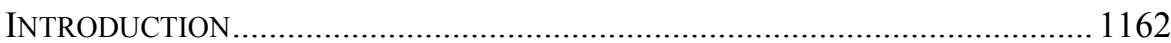

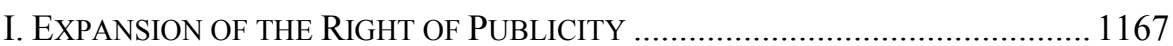

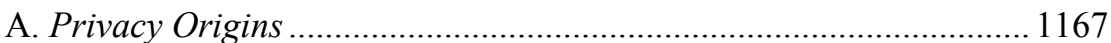

B. The Modern View: Fame as Property .............................................. 1172

C. Problem Cases: Referential Uses and Merchandise .......................... 1175

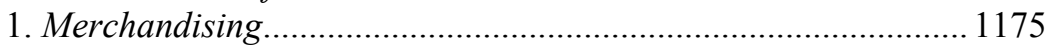

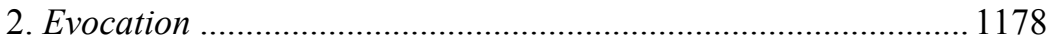

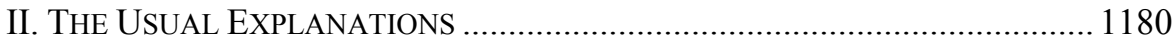

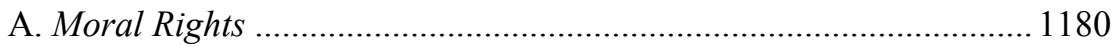

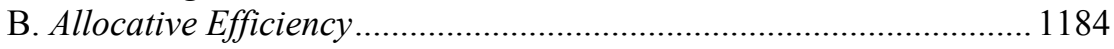

C. Incentive Models and Copyright ….................................................. 1186

III. TRADEMARK LAW: A BETTER ANALOGY ................................................ 1190

A. Explaining Right of Publicity Cases Using the Trademark

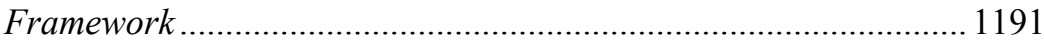

1. Likelihood of confusion ............................................................ 1191

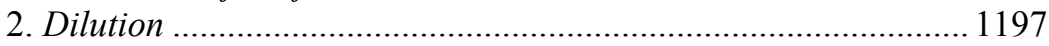

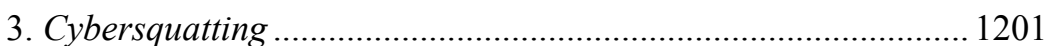

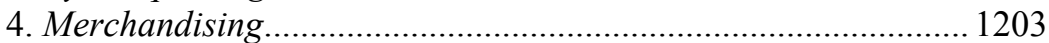

B. Do We Need a Separate Right of Publicity at All? ............................. 1208

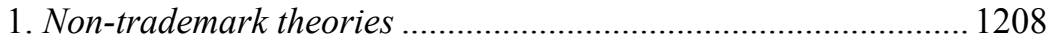

2. Imperfect fit of trademark protection ........................................... 1210

IV. IMPLICATIONS OF THE TRADEMARK APPROACH ..................................... 1213

A. Substantive Implications for Right of Publicity Doctrine.................... 1213

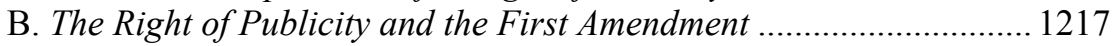

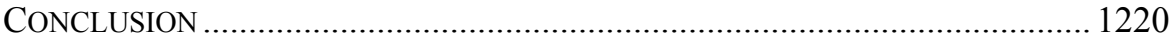

* Professor of Law, Northeastern University School of Law.

** William H. Neukom Professor, Stanford Law School; Director, Stanford Program in Law, Science, and Technology; Of Counsel, Keker \& Van Nest LLP.

We would like to thank Bhanu Sadasivan for research assistance. In fact, we'd like it so much we will thank her. Thanks, Bhanu! Thanks also to David Adelman, Graeme Austin, Michael Einhorn, Paul Goldstein, Rose Hagan, Bruce Keller, Bobbi Kwall, Jennifer Rothman, and participants in a workshop at the IP Works in Progress. 


\section{INTRODUCTION}

The right of publicity gives people the right to control the use of their names and likenesses for commercial purposes. For years, courts have struggled to make sense of two dimensions of this right - what it means to use a name or likeness "commercially," and what aspects of a person's "likeness" are protected against appropriation. In the absence of any clear theoretical foundation for the right of publicity, the meanings of these terms have steadily swelled, to the point at which virtually any reference to an individual that brings financial benefit to someone else qualifies as a violation of the right of publicity. ${ }^{1}$ At the same time, the courts have developed no meaningful counterweight to this ever-expanding right. Instead, they have created a few ad hoc exceptions in cases where the sweeping logic of the right of publicity seems to lead to results they consider unfair.

Two types of publicity claims have raised particular problems for the courts. The first involves "merchandising" claims, in which individuals claim violation of their publicity right not by the use of a name in advertising, but by the sale of products that bear their names or likenesses. Courts have generally resolved these claims by making a distinction between "news" or "speech," on the one hand, and "merchandise," on the other. But as art and information become increasingly commodified, this distinction - if it ever made sense-has become ever harder to sustain. ${ }^{2}$ The second type of problematic claim involves cases in which a use draws attention away from the celebrity or arguably sullies the celebrity's reputation in some way that harms the overall value of her identity. Properly limited, such a cause of action might have some theoretical appeal, but courts have applied it in ways that exceed any plausible theoretical justification, particularly when First Amendment considerations enter the fray.

One root of the problems with these cases lies in the elusiveness of a theoretical justification for the right of publicity. When the government can clearly identify a reason to limit speech, courts have some basis on which to evaluate whether the speech limitation lives up to that purpose. But because the right of publicity rests upon a slew of sometimes sloppy rationalizations, courts have little way of determining whether a particular speech limitation is

1. Indeed, some states suggest that any advantage — economic or otherwise — can lead to a right of publicity violation. See, e.g., Newton v. Thomason, 22 F.3d 1455, 1460 \& n.4 (9th Cir. 2005); White v. Samsung Elec. Am., Inc., 971 F.2d 1395, 1397 (9th Cir. 1992) (defining the right as applying to "appropriation of plaintiff's name or likeness to defendant's advantage, commercially or otherwise" (quoting Eastwood v. Superior Court, 198 Cal. Rptr. 342 (Ct. App. 1983)).

2. Cf. ETW Corp. v. Jireh Publ'g, Inc., 332 F.3d 915, 937 (6th Cir. 2003) (distinguishing between the First Amendment protection given to fine art, which was "expression," and that given to commercial art, which was "commercial speech"); Comedy III Prods., Inc. v. Gary Saderup, Inc., 21 P.3d 797, 810-11 (Cal. 2001) (attempting to distinguish between art that merely exploits and art that comments, and thereby falls within First Amendment protection). 
necessary or even appropriate in order to serve the law's normative goals. ${ }^{3}$ Instead, they appear to assume that the sum of a set of inadequate justifications equals far more than its parts and allow right of publicity claims to run roughshod over the speech interests of the public.

If the absence of a rationale has created the problem, then the answer lies in identifying whether and when a right of publicity might serve a legitimate government interest. Yet a review of the cases and literature reveals that no one seems to be able to explain exactly why individuals should have this right. A right of privacy can't justify it, for the right of publicity has been applied in a wide range of situations that don't implicate privacy at all. Some commentators have proposed a natural or moral right of control over one's name or likeness, ${ }^{4}$ but there seems to be no policy justification for giving such control, and the absence of such a right in most of the world and indeed throughout most of U.S. history should make us skeptical of claims based on some consensus moral belief. ${ }^{5}$ The moral claim to own the use of one's name also seems inconsistent with the absence of natural or moral rights justifications for other forms of intellectual property (IP) in the United States. ${ }^{6}$

Of late, and particularly in the merchandising cases, courts and commentators have looked to copyright law in an attempt to justify and delimit the right of publicity. On the affirmative side, they contend that copyright law's incentive-based rationale supports the publicity right. Reasoning that the right of publicity gives individuals the incentive to develop valuable personas, courts conclude that depriving those individuals of the fruits of their labors will interfere with those economic incentives. On the defense side, some courts have even gone so far as to create a fair use doctrine, importing from copyright law judicially created limits on the enforcement of the right. This approach turns the right of publicity into a new form of IP right, one based explicitly on analogies to and justifications for real property.

3. See Diane Leenheer Zimmerman, Who Put the Right into the Right of Publicity?, 9 DePaul-LCA J. ARt \& EnT. L. \& Pol'y 35, 47-49 (1998).

4. $1 \mathrm{~J}$. Thomas McCarthy, The Rights of Publicity and Privacy $\S 2: 1$ (2d ed. 2005); cf. Roberta Rosenthal Kwall, Preserving Personality and Reputational Interests of Constructed Personas Through Moral Rights: A Blueprint for the Twenty-First Century, 2001 U. ILL. L. REV. 151, 152 (noting parallels between moral rights and right of publicity).

5. Indeed, advocates of publicity rights in other countries use the United States as their model. See, e.g., Jan Klink, 50 Years of Publicity Rights in the United States and the NeverEnding Hassle with Intellectual Property and Personality Rights in Europe, 2003 InTELL. PROP. Q. 363, 387 (claiming that "50 years of daily practice have proven the advantages of separate publicity rights in the United States"). Japan recognized a right of publicity in 1976. See Hanrei Times (No. 1071) 294, Nagoya High Ct., Mar. 8, 2001.

6. As others have pointed out, intellectual property law in the United States often reflects undercurrents of moral rights considerations. See, e.g., Ilhyung Lee, Toward an American Moral Rights in Copyright, 58 WASH. \& LeE L. ReV. 795 (2001); Neil Netanel, Copyright Alienability Restrictions and the Enhancement of Author Autonomy: A Normative Evaluation, 24 RutgERS L.J. 347, 393-98 (1993). Nonetheless, the dominant model, and the one reflected in the U.S. Constitution, is utilitarian. See U.S. ConsT. art. I, § 8, cl. 8. 
Thinking about the right of publicity by analogy to IP law may indeed be helpful. But we think copyright is the wrong analogy for a number of reasons. First, in the United States, copyright law is utilitarian. We grant copyrights in order to encourage the creation of new works of authorship. There is no similar justification for the right of publicity. Society doesn't need to encourage more celebrities or more marketing of celebrity image. Nor is there any evidence that, even if such a result were desirable, a property-like right of publicity is well tailored to that goal. Second, copyright's fair use doctrine involves tradeoffs between the interests of original creators and those who would like to make transformative uses of their creative works. The right of publicity has no similar tradeoff. ${ }^{7}$ Third, copyright's fair use doctrine is confusing to the point of incoherence and is hardly a model anyone would wish to emulate. Finally, the analogy to copyright can obscure important free speech interests at stake in right of publicity cases. For better or worse, copyright laws have gotten a free ride when it comes to the First Amendment. The copyright analogy may prompt courts to mistakenly extend that free ride in the right of publicity context.

Logically, the right of publicity has more in common with trademark law than with copyright. The right of publicity protects a celebrity's interest in her name and likeness, much as trademark law protects a business's name and other trademarks. Both areas of law give rights-holders some measure of control over the meaning of their identities by permitting them to control the use of associated symbols. ${ }^{8}$ The Lanham Act has traditionally accomplished this end by preventing commercial uses of trademarks that are likely to confuse consumers regarding either the source of goods or the affiliation, endorsement, or sponsorship of those goods by the trademark owner. ${ }^{9}$ The right of publicity aims to do the same thing for celebrities by preventing the use of a celebrity's name or likeness in advertising or promotion to falsely suggest that she has endorsed the advertised product. Both forms of legal protection promote not only the rights-holder's interests, but also those of the public. Trademark holders and celebrities can prevent the deceptive appropriation of the meaning associated with their goodwill and identity, while consumers can buy products with confidence in the truth of assertions about who makes, sponsors, endorses, and stands behind those goods. ${ }^{10}$

7. There is a tradeoff of interests between the celebrity and the user, of course, but because the celebrity is not creating anything, there is no utilitarian balancing calculus analogous to that in copyright.

8. See Mark P. McKenna, The Right of Publicity and Autonomous Self-Definition, 67 U. PITT. L. REV. (forthcoming 2006).

9. See 15 U.S.C. § 1114(1) (2006); 15 U.S.C. § 1125(a) (2006).

10. Arguably no one should care whether or not Catherine Zeta-Jones endorses one particular brand of cell phone. But apparently we do: celebrity product endorsement is big business. In a market economy, the right of publicity quite reasonably takes this consumer preference as a given and tries to make sure that even if consumers are irrational in preferring celebrity-endorsed products, they are at least not deceived as to the endorsement 
More recently, the Lanham Act has been expanded to prevent dilution of famous trademarks by commercial uses that draw attention away from the trademark owner or throw it into disrepute, even if the uses do not confuse the public. Dilution, too, has analogies in the right of publicity. Uses of a celebrity's name might in rare circumstances undermine the connection between the name and that celebrity or, more likely, might tarnish the reputation of the celebrity by using her name or likeness in a disreputable connection, even in the absence of confusion or assumptions of endorsement. In these narrow circumstances, a cause of action may be appropriate.

Finally, a few courts have expanded trademark law to include a general right to control the merchandising of goods bearing a trademark even in the absence of confusion or dilution, though this expansion rests on dubious legal grounds. This merchandising right too has analogues in the right of publicity. Indeed, the emergence of a property-like form of the right of publicity can best be understood as an adoption of the putative trademark merchandising right, with judicial decisions reflecting the same anti-free-riding instincts that informed the merchandising cases in the trademark context.

Reconceiving the right of publicity as a trademark-like right offers significant benefits in defining the right's scope and limitations. First, it provides a helpful way to think about the different sorts of claims made under the rubric of publicity. We have considerable experience with each of these types of claims in trademark law, and applying that knowledge to right of publicity cases can help us understand why we might (or might not) want to prohibit particular uses. Most importantly, looking at the right of publicity through the lens of trademark law offers logical ways to limit the right. Trademarks are not property rights in the traditional sense, though a few courts and commentators have suggested that trademark owners should have propertylike rights over their marks. Trademark cases tend instead to be decided either based on likelihood of confusion or on dilution grounds, both of which bear a clear relationship to the goal of protecting trademarks as informational symbols in the marketplace. ${ }^{11}$ Both trademark infringement and dilution also

of those products.

11. Trademark law has, of course, witnessed occasional departures from this goal, both in the merchandising cases and in a series of recent cases involving the Internet. See, e.g., Playboy Enters. v. Netscape Commc'ns, 354 F.3d 1020, 1034 (9th Cir. 2004) (allowing claim against Internet search engine that used trademark as keyword to generate advertisements); Boston Prof'l Hockey Ass'n v. Dallas Cap \& Emblem Mfg., 510 F.2d 1004 (5th Cir. 1975) (holding that trademark claim in merchandising context does not require confusion). As we have pointed out elsewhere, however, both of these expansions are problematic as a matter of trademark law and hardly deserve emulation in the right of publicity context. See Stacey L. Dogan \& Mark A. Lemley, The Merchandising Right: Fragile Theory or Fait Accompli?, 54 EMORY L.J. 461 (2005) (discussing the merchandising theory) [hereinafter Dogan \& Lemley, Merchandising Right]; Stacey L. Dogan \& Mark A. Lemley, Trademarks and Consumer Search Costs on the Internet, 41 Hous. L. REV. 777 (2004) (discussing Internet-related expansions) [hereinafter Dogan \& Lemley, Trademarks and Consumer Search Costs]. 
incorporate significant limiting principles designed to balance the interests of other parties against the interests of trademark owners and to accommodate First Amendment concerns. The failure to incorporate these limitations into the right of publicity has resulted in a mutant version of trademark policy that promotes some of the law's objectives, but views them in isolation, with neither contours nor counterweight.

If, as we believe, a properly conceived right of publicity promotes the same core goals as trademark law, then a proper understanding of the right of publicity would draw more completely on trademark principles in defining the scope and the limitations of the publicity right. The overlap is not perfect, and we anticipate some continuing role for a separate publicity right, but the trademark framework should suit the vast majority of right of publicity cases. Even when it doesn't, understanding the differences between trademark law and the right of publicity will help us to comprehend and cabin the publicity right. Doctrinally, such an approach would limit the right to circumstances in which the use of an individual's name or likeness in connection with the sale of a product is likely either to confuse consumers or to dilute the significance of a famous name. ${ }^{12}$ Revising the right of publicity to conform to the rules we have worked out in trademark cases will avoid some of the worst abuses of the right, limit the conflict between the right of publicity and First Amendment principles, and put the right on a more solid conceptual grounding.

In Part I, we describe the growth of the right of publicity from its narrow privacy origins to a virtually unlimited, descendible, assignable property right. Part I discusses two particular excesses that this trend has brought about and that are increasingly creating problems for the courts and the public: the expanding merchandising right and the dilution-like cause of action. Part II discusses the existing efforts to explain the growth of the right of publicity. Those explanations have generally focused on incentive-based rationales akin to copyright law - rationales whose logic breaks down in the right of publicity context. Part II goes on to explain why copyright law proves inadequate to justify the right of publicity and to define its scope, with particular reference to merchandising and dilution-like cases. In Part III, we offer a new explanation for the right of publicity, one based in trademark principles. Part III shows how the right of publicity has adopted some but not all of the rules of trademark law and how a more complete importation of trademark principles into publicity law would solve many of the problems that plague the doctrine. Finally, in Part

12. There is one exception. Occasional right of publicity cases draw on the traditional conception of the tort as a privacy right, rather than on a property-based attempt to control revenue from commercial exploitation of a celebrity persona. E.g., Minnifield v. Ashcraft, 903 So. 2d 818, 824 (Ala. Civ. App. 2001) (recognizing "commercial-appropriation invasion-of-privacy tort" in suit against tattoo parlor for unauthorized publication of photographs of a tattoo on plaintiff's breast). The use of the right of publicity to protect privacy does not draw on trademark principles, and it may provide an alternative basis for a publicity claim. See infra notes $224-30$. It is a relatively minor alternative basis, however; most modern publicity cases are not in fact efforts to protect privacy. 
IV we consider some objections and compare our approach to alternative approaches for dealing with the problems of the publicity right.

\section{EXPANSION OF THE RIGHT OF PUBLICITY}

Before the late nineteenth century, individuals had little recourse against the use of their names or images by unauthorized parties. Except in the unusual cases of libel or trademark infringement, ${ }^{13}$ individuals could do nothing to prevent the use of their identities for either commercial or noncommercial purposes. ${ }^{14}$ It is hard to overstate the contrast between then and now. These days, virtually any profit-oriented use of a name or identity is presumed to be wrongful, with the defendant bearing the burden of establishing that its use falls within some protected exception. How did we get here?

While one could slice the history in many different ways, we find it useful to divide the right of publicity's evolution into two general phases: the privacy phase and the modern phase. The privacy phase - which began in the late 1800 s - involved the courts' recognition, for the first time, of the right of individuals to limit the use of their names or likenesses by commercial actors. Most privacy cases involved noncelebrities, and the privacy phase is thus often treated as a precursor to the right of publicity rather than a first step in its evolution. ${ }^{15}$ In fact, however, many courts interpreted the right of privacy to encompass an important publicity-like right: the right against false endorsements, available to celebrities and noncelebrities alike. A half century later, courts and legislatures began to recognize a much broader right of celebrities to prevent commercial use of their identities, without regard to whether the use suggested false endorsement or whether the celebrity had actively sought out the spotlight. It was this shift in emphasis-from protecting the integrity of an individual's identity to protecting the economic value of celebrity as an alienable economic right - that ushered in the modern age of publicity rights, with all its attendant tensions.

\section{A. Privacy Origins}

In 1890, Samuel Warren and Louis Brandeis wrote their famous law

13. Trademark infringement, at the time, was defined much more restrictively than today, requiring not only that the mark at issue qualify as a trademark, but also that the infringer use a virtually identical mark on a directly competing product. See, e.g., Borden Ice Cream Co. v. Borden's Condensed Milk Co., 201 F. 510 (7th Cir. 1912) (finding no infringement of Borden milk mark by seller of Borden ice cream).

14. See Michael Madow, Private Ownership of Public Image: Popular Culture and Publicity Rights, 81 CAL. L. REV. 127, 148-52 (1993) (describing widespread commercial exploitation of celebrity images through the late 1800s).

15. E.g., id. at 167 ("The right of publicity was created not so much from the right of privacy as from frustration with it."). 
review article proposing a new "Right to Privacy." technological and cultural developments that had shrunk the realm of the private $^{17}$ and called for courts to reverse this trend by recognizing a right of individuals "to be let alone." 18 A privacy right, the authors asserted, would serve two important goals. First and most obviously, it would redress the harms that private individuals suffered from invasions of their privacy-harms that the authors described as "mental pain and distress, far greater than could be inflicted by mere bodily injury." 19 But the authors professed a more overarching goal: to arrest what they perceived as a downward spiral in the content and quality of journalism in the United States. ${ }^{20}$ "Triviality," they asserted, "destroys at once robustness of thought and delicacy of feeling. No enthusiasm can flourish, no generous impulse can survive under its blighting influence." 21 By forbidding the publication of idle gossip (at least without permission), Warren and Brandeis apparently believed that they could restore "propriety" and "decency" to the press. ${ }^{22}$

The legal claim proposed by Warren and Brandeis reflected their core concern with avoiding crass invasions by an overreaching press. Although their article occasionally strayed into broad generalities suggesting that individuals should have property rights in their personalities, ${ }^{23}$ their proposed cause of

16. Samuel D. Warren \& Louis D. Brandeis, The Right to Privacy, 4 HARV. L. REv. 193 (1890).

17. Id. at 195 ("Instantaneous photographs and newspaper enterprise have invaded the sacred precincts of private and domestic life; and numerous mechanical devices threaten to make good the prediction that "what is whispered in the closet shall be proclaimed from the house-tops."'). The authors purportedly seized upon the subject after a newspaper published intimate details of a Warren-family event. See William L. Prosser, Privacy, 48 CAL. L. Rev. 383, 383 (1960); cf. Benjamin E. Bratman, Brandeis and Warren's The Right to Privacy and the Birth of the Right to Privacy, 69 TENN. L. REv. 623, 629 \& n.28 (2002) ("Although there is some disagreement among scholars over whether Warren was disturbed about a specific report in a Boston newspaper regarding private affairs of his own family, Warren was, by all accounts, the one who initiated the idea of writing the article.").

18. Warren \& Brandeis, supra note 16, at 205.

19. Id. at 196.

20. Warren and Brandeis believed that the newspapers, by publishing unsavory gossip, had driven demand for such content and thereby impaired public literacy. Id. ("In this, as in other branches of commerce, the supply creates the demand .... Easy of comprehension, appealing to that weak side of human nature which is never wholly cast down by the misfortunes and frailties of our neighbors, no one can be surprised that it usurps the place of interest in brains capable of other things.").

21. Id.

22. Id. A century later, the debate over the relationship between privacy and the press persists. See, e.g., Rodney A. Smolla, Privacy and the First Amendment Right To Gather News, 67 Geo. WASH. L. Rev. 1097, 1097 (1999) (exploring "whether laws should be passed to curb the practices of paparazzi, and whether the media should be liable for engaging in aggressive newsgathering techniques or for publishing private facts").

23. See Warren \& Brandeis, supra note 16, at 205 (discussing individuals' interest in their "inviolate personality"); $i d$. at 207 (identifying a "right to privacy, as a part of the more general right to the immunity of the person, the right to one's personality"); id. at 211 ("The 
action focused narrowly on the problem at hand: "to protect the privacy of private life." 24 As such, the right would not apply to information that the individual had voluntarily disclosed ${ }^{25}$ or to information in which the public had a legitimate interest. The right, instead, should apply only to the publication of "matters ... which concern the private life, habits, acts, and relations of an individual, and have no legitimate connection" with his public position or with "any act done by him in a public or quasi public capacity." 26

Slowly at first, and then with increasing enthusiasm, courts and legislatures in the early twentieth century began to respond to the call for a right to privacy. ${ }^{27}$ While privacy interests took a variety of different forms in the law, ${ }^{28}$ one of the strands - which William Prosser later identified as "[a]ppropriation, for the defendant's advantage, of the plaintiff's name or likeness"29 — reflected an early form of the publicity right. The New York privacy statute was typical, imposing liability against the unauthorized use of the "name, portrait or picture of any living persons" for "advertising purposes or for the purposes of trade."30

Factually, most of these "commercial appropriation" privacy cases involved the unauthorized use of a personal name or photograph in connection

right of property in its widest sense, including all possession, including all rights and privileges, and hence embracing the right to an inviolate personality, affords alone that broad basis on which the protection which the individual demands can be rested."); see also Corliss v. E.W. Walker Co., 64 F. 280, 282 (C.C.D. Mass. 1894) (“[A] private individual has a right to be protected in the representation of his portrait in any form," and "this is a property as well as a personal right."); $c f$. Schuyler v. Curtis, 42 N.E. 22, 28 (N.Y. 1895) (Gray, J., dissenting) ("I cannot see why the right of privacy is not a form of property, as much as is the right of complete immunity in one's person.").

24. Warren \& Brandeis, supra note 16, at 215.

25. Id. at 218 ("The right to privacy ceases upon the publication of the facts by the individual, or with his consent.").

26. Id. at 216.

27. See Madow, supra note 14, at 167-69 (describing the history of the right to privacy).

28. William Prosser identified four different categories of privacy-related torts: (1) intrusion into private affairs, (2) public disclosure of embarrassing facts, (3) "false light" privacy invasion - that is, publicly presenting a party in a false light, and (4) appropriation of a name or likeness for the defendant's economic advantage. Prosser, supra note 17, at 389. More generally, commentators have identified numerous ways in which state and federal law recognize privacy interests. See Ken Gormley, One Hundred Years of Privacy, 1992 WIs. L. REV. 1335, 1340, 1342-43 (identifying five disparate areas of privacy law, including constitutional privacy principles, whose origins trace back to Warren and Brandeis's article).

29. Prosser, supra note 17 , at 389.

30. Act of Apr. 6, 1903, ch. 132, §§ 1-2, 1903 N.Y. Laws 308 (codified as amended at N.Y. Civ. Rights Law $\S \S 50,51$ (McKinney 2002)). The New York law was passed in response to the New York Court of Appeals' refusal to recognize the privacy right as a matter of common law. Roberson v. Rochester Folding Box Co., 64 N.E. 442, 447 (N.Y. 1902). See generally Madow, supra note 14, at 167 \& n.202; Lawrence E. Savell, Right of Privacy-Appropriation of a Person's Name, Portrait, or Picture for Advertising or Trade Purposes Without Prior Written Consent: History and Scope in New York, 48 ALB. L. REV. 1, 3-14 (1983). 
with product advertising. ${ }^{31}$ A number of them also included demonstrably false statements that would be separately actionable under today's unfair competition laws. ${ }^{32}$ Despite the fairly narrow factual context of the claims, however, the courts tended to describe the new privacy right in extremely broad terms, often suggesting a property-like interest of individuals in their personal image. ${ }^{33} \mathrm{At}$ the same time, they acknowledged a tension between individuals' privacy interests and the interest of the public in access to information and suggested that public figures' privacy rights would be more limited than those of purely private individuals. ${ }^{34}$ Thus, the cases involving well-known individuals tended to involve blatant misrepresentations that could harm their reputations in the community. ${ }^{35}$ The cause of action, in other words, remained deeply rooted in

31. See, e.g., Pavesich v. New Eng. Life Ins. Co., 50 S.E. 68 (Ga. 1905) (upholding privacy claim based on use of plaintiff's photograph in life-insurance advertisement that included false statements about his relationship with the insurance company); Kunz v. Allen, 172 P. 532 (Kan. 1918) (finding violation of right of privacy based on the use of clandestinely recorded footage of plaintiff in advertisement for dry-goods store); FosterMilburn Co. v. Chinn, 120 S.W. 364, 366 (Ky. 1909) (allowing privacy claim when defendant had used a false testimonial by plaintiff in its advertisement, stating that "a person is entitled to the right of privacy as to his picture, and ... the publication of the picture of a person without his consent, as a part of an advertisement for the purpose of exploiting the publisher's business, is a violation of the right of privacy"); Munden v. Harris, $134 \mathrm{~S}$.W. 1076 (Mo. App. 1911) (upholding privacy claim based on unauthorized use of child's photograph in advertisement for jewelry); Edison v. Edison Polyform Mfg. Co., 67 A. 392, 394 (N.J. Ch. 1907) (finding privacy right violation when defendant's product labels included both a picture of Thomas Edison and a false Edison testimonial regarding the formula for defendant's products).

32. See cases cited supra note 31 .

33. See, e.g., Pavesich, 50 S.E. at 80 ("If one's picture may be used by another for advertising purposes, it may be reproduced and exhibited anywhere. If it may be used in a newspaper, it may be used on a poster or a placard. It may be posted upon the walls of private dwellings or upon the streets. It may ornament the bar of the saloon-keeper, or decorate the walls of a brothel. By becoming a member of society, neither man nor woman can be presumed to have consented to such uses of the impression of their faces and features upon paper or upon canvas."); Munden, 134 S.W. at 1079 ("We therefore conclude that one has an exclusive right to his picture, on the score of its being a property right of material profit."); Edison, 67 A. at 394 ("If a man's name be his own property ... it is difficult to understand why the peculiar cast of one's features is not also one's property, and why its pecuniary value, if it has one, does not belong to its owner, rather than to the person seeking to make an unauthorized use of it.").

As a theoretical basis for the cause of action, courts generally turned to natural law. See, e.g., Pavesich, 50 S.E. at 70 ("A right of privacy in matters purely private is therefore derived from natural law.").

34. E.g., Corliss v. E.W. Walker Co., 64 F. 280, 282 (C.C.D. Mass. 1894).

35. E.g., Mackenzie v. Soden Mineral Springs Co., 18 N.Y.S. 240 (Sup. Ct. 1891) (enjoining use of well-known physician's name in connection with the sale of medicine, reasoning that "[t]he labels were injurious to plaintiff"s professional reputation"); State v. Hinkle, 229 P. 317, 319 (Wash. 1924) (The court enjoined unauthorized use of politician's name in connection with a political party, stating that "[n]othing so exclusively belongs to a man or is so personal or valuable to him as his name. His reputation and the character he has built up are inseparably connected with it."). 
offense to person, to acts that caused "pain and mental stress" by stripping celebrities of control over their reputations and associational choices.

The privacy roots of the early identity appropriation claim had several implications for celebrities. First, the mere publication of their photographs or images was typically not viewed by courts as an invasion of any privacy interest, because the celebrities had actively sought out their fame and could not be offended by its furtherance. ${ }^{36}$ Second, while a celebrity could sometimes prevail on a theory that the defendant had falsely suggested her endorsement of its product, courts generally held that the mere use of the celebrity's image, even in advertising, did not suggest such endorsement. ${ }^{37}$ Third, even when celebrities prevailed in privacy cases, their damages were limited to the personal injury that they suffered, rather than the economic value that the use brought to the advertiser. ${ }^{38}$ And finally, since the right of privacy was a personal right, it ran with the person and could not be transferred or survive the death of the celebrity. ${ }^{39}$ These limitations led celebrities and their advocates to push for a different, more economically oriented right in their personas. ${ }^{40}$

36. See, e.g., O’Brien v. Pabst Sales Co., 124 F.2d 167, 170 (5th Cir. 1941) ("Assuming then, what is by no means clear, that an action for right of privacy would lie in Texas at the suit of a private person, we think to [sic] clear that the action fails; because plaintiff is not such a person and the publicity he got was only that which he had been constantly seeking and receiving."); Smith v. Suratt, 7 Alaska 416, 423 (1926) (refusing to enjoin the unauthorized filming of a privately funded Arctic expedition since "as a public enterprise in which everybody is interested, and in which the public at large is interested, it cannot claim any rights of privacy"); $c f$. Corliss, 64 F. at 282 ("A private individual should be protected against the publication of any portraiture of himself, but where an individual becomes a public character the case is different. A statesman, author, artist, or inventor, who asks for and desires public recognition, may be said to have surrendered this right to the public.”). But see Lane v. F.W. Woolworth Co., 11 N.Y.S.2d 199, 200 (Sup. Ct. 1939) (enjoining sale of locket with actress's picture inside, without regard to false endorsement, when "[t]he photograph was obviously used to bring attention to the lockets on display to make them more attractive").

37. See Hanna Mfg. Co. v. Hillerich \& Bradsby Co., 78 F.2d 763 (5th Cir. 1935) (refusing to allow bat company, which had license to use ballplayers' signatures on bats, to sue competitor that used baseball players' names to denote style of competing bats); Martin v. F.I.Y. Theatre Co., 1 Ohio Supp. 19, 23 (Com. Pl. 1938) ("An actress of the accomplishments and reputation claimed for this plaintiff is no longer a private individual, but has become a public character and cannot complain that any right of privacy is trespassed upon the mere unauthorized publication of a photograph.").

38. Cf. Pavesich, 50 S.E. at 73 (noting that tort damages, such as "recovery of damages for wounded feelings," are available in right of privacy cases).

39. See Melvin v. Reid, 297 P. 91,93 (Cal. App. 1931); Atkinson v. Doherty \& Co., 80 N.W. 285 (Mich. 1899); Schuyler v. Curtis, 42 N.E. 22, 25 (N.Y. 1895) ("Death deprives us all of rights in the legal sense of that term, and when Mrs. Schuyler died, her own individual right of privacy, whatever it may have been, expired at the same time.").

40. See, e.g., Recent Cases, 49 Harv. L. Rev. 478, 496 (1936) (analyzing Hanna Manufacturing Co.). See generally Madow, supra note 14, at 172 (noting that, as a result of changes in communication and advertising practices, "some people began to conceive of fame as an instrumental good, a business asset like 'good will,' a commodity to be produced and exchanged like any other'). The dissent in O'Brien v. Pabst planted the seeds for such a 


\section{B. The Modern View: Fame as Property}

Celebrities frustrated with the right of privacy found their vindication in 1953, when the Second Circuit decided Haelan v. Topps Chewing Gum. ${ }^{41}$ The case involved competing chewing gum manufacturers that used baseball trading cards as a device to help sell their gum. Haelan had obtained exclusive licenses from a number of ballplayers authorizing the use of their images on its baseball cards. When Topps sold its own gum with photographs of these same players, ${ }^{42}$ Haelan sued for violation of its "exclusive rights" to the players" images. ${ }^{43}$

The court agreed with defendant that plaintiff could not recover under New York's statutory privacy law, ${ }^{44}$ but nonetheless ruled in favor of plaintiff based on a new common law right that it dubbed the "right of publicity":

We think that, in addition to and independent of that right of privacy (which in

New York derives from statute), a man has a right in the publicity value of his

photograph, i.e., the right to grant the exclusive privilege of publishing his

picture, and that such a grant may validly be made 'in gross,' i.e., without an accompanying transfer of a business or of anything else. ${ }^{45}$

The court gave no doctrinal or policy justification for its decision, offering instead a conclusory statement that "New York decisions recognize such a right" and citing three cases that did no such thing. ${ }^{46}$ By way of explanation, the court stated merely that:

$[\mathrm{M}]$ any prominent persons ... would feel sorely deprived if they no longer received money for authorizing advertisements, popularizing their

claim. See 124 F.2d at 171 (Holmes, J., dissenting) ("It appears [from the complaint] that the appellee committed a tort in misappropriating a valuable property right of appellant.") (emphasis added).

41. Haelan Labs., Inc. v. Topps Chewing Gum, Inc., 202 F.2d 866 (2d Cir. 1953).

42. Topps had obtained licenses to use at least some of the photographs from Russell Publishing Company, a third party who allegedly induced the players to violate their exclusive contract with Haelan. The court noted that the plaintiff would have a cause of action for such inducement against Russell, or against Topps in cases in which Topps had induced the breach directly or through its agents. Id. at 868 .

43. Id.

44. Id. (referring to the right of privacy as "a personal and non-assignable right not to have his feelings hurt by such a publication"). The New York Court of Appeals has since held that at least some aspects of the right of publicity properly fall within the right of privacy statute. See Stephano v. News Group Publ'ns, Inc., 474 N.E.2d 580, 584 (N.Y. 1984).

45. Haelan, 202 F.2d at 868 .

46. See id. (citing Wood v. Lucy, Lady Duff Gordon, 118 N.E. 214 (N.Y. 1917) (breach of contract claim); Madison Square Garden Corp. v. Universal Pictures Co., 7 N.Y.S.2d 845 (App. Div. 1938) (misappropriation claim based on a movie's deceptive suggestion that it depicted an actual Madison Square Garden hockey game); Liebig's Extract of Meat Co. v. Liebig Extract Co., 180 F. 688 (2d Cir. 1910) (granting injunction against individual's use of his own name in trade, based on his prior transfer of trademark rights in the name to another party)). 
countenances, displayed in newspapers, magazines, busses, trains and subways. This right of publicity would usually yield them no money unless it could be made the subject of an exclusive grant which barred any other advertiser from using their pictures. 47

Haelan's new cause of action differed from the right of privacy in several important ways. Most significantly, as an economic rather than a personal right, the right of publicity was fully alienable, meaning that third parties could acquire a celebrity's publicity rights and have standing to sue for violations. ${ }^{48}$ In some cases, such third parties were profit-oriented assignees concerned with maximizing the revenues from the celebrity's fame, but not necessarily with preserving the values of privacy and personal integrity upon which the right of privacy so heavily relied. The new emphasis on maximizing celebrities' economic returns also had implications for damages: in addition to injunctive relief, celebrities (or their licensees) could now seek damages in the form of customary endorsement fees, rather than limiting themselves to the type of actual, personal harm contemplated by the right of privacy. 49

At the same time, the Second Circuit's opinion left open critical questions about the content of the new right. In particular, because Haelan itself involved a use of images in products, the court did not face the question of whether the publicity right applied only in that context or extended to other profit-making uses of celebrity identity. Nor did the court determine whether the publicity right could survive the death of the celebrity. Indeed, the theoretical vacuum through which the court introduced the publicity right left courts with very little insight into the values that should guide them as they applied the law to new facts. ${ }^{50}$ While it took a couple of decades for the right of publicity to take hold, ${ }^{51}$ by the late 1970 s it had gained traction in both courts and legislatures around the country. Unfortunately, rather than fill Haelan's vacuum with considered analysis, judges and lawmakers sidestepped the tough issues and

47. Haelan, 202 F.2d at 868.

48. Indeed, the perceived need for alienability was what drove the recognition of the new right in Haelan, because the personal right of privacy would not have allowed Haelan, a licensee, to sue. Alienability, of course, increased the value of the right by ensuring that exclusive licensees or transferees received the full value of the celebrity's image. But as Melissa Jacoby and Diane Zimmerman point out, it can also reduce the value of the right to the celebrity herself, by reducing the control she has over the use of her name. See Melissa B. Jacoby \& Diane Leenheer Zimmerman, Foreclosing on Fame: Exploring the Uncharted Boundaries of the Right of Publicity, 77 N.Y.U. L. REV. 1322 (2002).

49. Id. See generally ReSTATEMENT (THIRD) OF UNFAIR COMPETITION $§ 49$ (1995) (stating that damages can include celebrity's pecuniary loss "or... the actor's own pecuniary gain resulting from the appropriation, whichever is greater").

50. A year after Haelan, Melvin Nimmer wrote an article defending the new right of publicity and attempting to give it some theoretical footing. His explanation for the right"that every person is entitled to the fruit of his labors unless there are important countervailing public policy considerations"-relied upon Lockean labor theory, which breaks down under further scrutiny. See infra note 93 and accompanying text.

51. See 1 MCCARTHY, supra note 4 , $\S 1$ 1:31, 1:32; Madow, supra note 14 , at 176-77 (discussing history). 
increasingly adopted an attitude of "if value, then right." 52

Since Haelan was decided, more than half of the states have adopted some form of a right of publicity, either through common law or statute. ${ }^{53}$ With some variation, the laws proscribe any unauthorized use of an individual's identity for commercial purposes or "for purposes of trade." the right to advertising, and indeed the Restatement identifies merchandising uses as among the uses targeted by the law. ${ }^{55}$ And while most states historically viewed the right as nondescendible, the modern trend holds it capable of surviving the death of the celebrity. ${ }^{56}$ The right of publicity has been applied in a wide range of cases: sound-alikes; ${ }^{57}$ look-alikes $;{ }^{58}$ use of the celebrity's nickname in a fictional work $;{ }^{59}$ use of address; ${ }^{60}$ statues $;{ }^{61}$ and the use of a

52. Rochelle Cooper Dreyfuss, Expressive Genericity: Trademarks as Language in the Pepsi Generation, 65 Notre DAME L. Rev. 397, 405 (1990); cf. Felix Cohen, Transcendental Nonsense and the Functional Approach, 35 CoLUM. L. REV. 809, 815 (1935) (discussing trademark law and stating that " $\mathrm{t}]$ he vicious circle inherent in this reasoning is plain. It purports to base legal protection upon economic value, when, as a matter of actual fact, the economic value of a sales device depends upon the extent to which it will be legally protected").

David Westfall and David Landau argue that this expansion may be self-perpetuating: "[O]nce an article acquires one of the attributes of property, legal actors will label it property and thus it will tend to acquire the other traditional attributes of property as well." David Westfall \& David Landau, Publicity Rights as Property Rights, 23 CARDOzo ARTS \& ENT. L.J. 71, 71 (2005). They explain that the right of publicity is one of a number of legal rights for which this has occurred.

53. 1 MCCARTHY, supra note $4, \S 6: 3$.

54. See Restatement (Third) OF Unfair COMPetition $\S 46$ (1995); $c f .1$ McCarthy, supra note $4, \S 3.2$ ("Rather, what is required is proof that the defendant intended to obtain a commercial advantage.").

55. RESTATEMENT (THIRD) OF UNFAIR COMPETITION $§ 47$ (1995) ("The name, likeness, and other indicia of a person's identity are used 'for purposes of trade' . . if they are used in advertising the user's goods or services, or are placed on merchandise marketed by the user, or are used in connection with services rendered by the user."); see also Brinkley v. Casablancas, 438 N.Y.S.2d 1004, 1008 (App. Div. 1981) (holding that sale of poster of celebrity was a sale "for trade purposes" within the language of the New York privacy statute).

56. 2 MCCARTHY, supra note $4, \S 9: 18$.

57. E.g., Midler v. Ford Motor Co., 849 F.2d 460 (9th Cir. 1988) (recognizing right of publicity claim against advertiser that hired singer to imitate Bette Midler's voice for use in automobile advertisement).

58. E.g., Allen v. Nat'l Video, Inc., 610 F. Supp. 612, 624 (S.D.N.Y. 1985) (allowing claim by Woody Allen against video-rental company that used Allen impersonator in its advertisements); $c f$. Motschenbacher v. R.J. Reynolds Tobacco Co., 498 F.2d 821 (9th Cir. 1974) (holding that race-car driver had right of publicity claim against advertiser that used footage of his race car in its advertisements, even when the image of the car was modified to remove distinctive features and the driver's personal likeness was not identifiable).

59. E.g., Doe v. TCI Cablevision, 110 S.W.3d 363 (Mo. 2003) (en banc) (upholding right of publicity claim based on comic book that used hockey player's nickname, "Tony Twist," as the name of a fictional character in the book).

60. Villalovos v. Sundance Assocs., No. 01 C 8468, 2003 WL 115243, at*2-5 (N.D. Ill. Jan. 13, 2003) (recognizing privacy and publicity claims by noncelebrity against 
robot that barely resembles the celebrity but evokes her image. ${ }^{62}$ The only internal limitation of the right lies in the meaning of "for purposes of trade" or "commercial purposes." And while some courts have incorporated First Amendment principles into their definition of "commercial," limiting commercial use of a personality to cases in which the celebrity is advertising or otherwise helping to sell the product, ${ }^{63}$ others apply a broad meaning of that term, concluding that any use of a name or likeness by which anyone makes money is therefore "commercial."

\section{Problem Cases: Referential Uses and Merchandise}

The apparently absolute nature of the right to prevent commercial uses, together with the breadth of the term "commercial," means that courts often presume a violation from any use of celebrity identity, with the defendant bearing the burden of establishing that its use was protected by the First Amendment or some other limiting doctrine.

Two types of cases are particularly troubling: those involving the sale of merchandise bearing a celebrity likeness and those involving reference to (but no direct use of) the celebrity's identity in advertisements.

\section{Merchandising}

Merchandising involves the use of celebrity image, not merely as a device to draw attention to a standalone product, but as an integral part of the product itself. Artists depict celebrities in posters, t-shirts, buttons, and other consumer products, and consumers buy them, not because they think the celebrity endorsed the product, ${ }^{64}$ but because they admire the celebrity and seek to

pornographic magazine that published her name and address in connection with a lewd advertisement based, in part, on the conclusion that "[a] valid address may identify a person more specifically than just a name, which often identifies not just one but several people").

61. E.g., Martin Luther King, Jr., Ctr. for Soc. Change, Inc. v. Am. Heritage Prods., Inc., 296 S.E.2d 697, 703 (Ga. 1982) (“[T] he appropriation of another's name and likeness, whether such likeness be a photograph or sculpture, without consent and for the financial gain of the appropriator is a tort in Georgia.").

62. White v. Samsung Elecs. Am., Inc., 971 F.2d 1395, 1395 (9th Cir. 1992) (finding that, by evoking Vanna White's image, advertiser had appropriated her identity within the meaning of California's right of publicity law). See generally 1 MCCARTHY, supra note 4 , $\S \S$ 4:45-4:87 (summarizing forms of identity appropriation that courts have found to violate the right of publicity).

63. E.g., Valentine v. CBS, Inc., 698 F.2d 430, 433 (11th Cir. 1983); Lane v. MRA Holdings, 242 F. Supp. 3d 1205 (M.D. Fla. 2002); Tyne v. Time Warner Entm't Co., 901 So. 2d 802 (Fla. 2005). "Commercial speech" in the First Amendment sense is speech that does no more than propose a commercial transaction. See Cent. Hudson Gas \& Elec. Corp. v. Pub. Serv. Comm'n, 447 U.S. 557, 562-63 (1980).

64. See ETW Corp. v. Jireh Publ'g, Inc., 332 F.3d 915, 922 (6th Cir. 2003) ("No reasonable person could believe that merely because these photographs or paintings contain 
associate themselves with her.

Merchandising cases differ from the traditional advertising-use cases in two important ways. First, they rarely raise the same concerns about celebrities' loss of personal integrity as the advertising cases do. When I sell an adulatory tshirt bearing a picture of Tiger Woods, I do not threaten his control over the meaning associated with his persona by suggesting his endorsement of some product, service, or business; to the contrary, I am validating and reinforcing the allure of the image that he himself has seen fit to convey to the public. ${ }^{65}$ Second, the merchandising cases involve important countervailing interests on the part of those who make and buy the merchandise. Unlike advertising uses, which employ celebrity identities purely to "propose a commercial transaction," element of the product itself. ${ }^{67}$ Buyers have an interest in accessing these images to show their admiration of and affiliation with cultural icons. Sellers often have their own expressive interest in presenting the celebrity image through their own artistic lens. Giving celebrities control over these uses of their images also has important economic consequences, impeding competition in the markets for such merchandise. ${ }^{68}$

[Tiger] Woods's likeness or image, they all originated with Woods."). In some situations, the context of the sale, together with the nature of the product, may cause consumers to believe that the celebrity endorsed the product. Nothing in the cases or literature, however, suggests that people assume such endorsement generally, or even that confusion as to endorsement is a relevant consideration in right of publicity cases.

65. See F. Jay Dougherty, All the World's Not a Stooge: The "Transformativeness" Test for Analyzing a First Amendment Defense to a Right of Publicity Claim Against Distribution of a Work of Art, 27 COLUM. J.L. \& ARTS 1, 62 (2003-04) ("[T]o the extent that the right of publicity protects against appropriation of the associative value of one's persona - the enhanced value to another product or service-it should not be considered violated by the sale of an image itself.").

66. See Comedy III Prods., Inc. v. Gary Saderup, Inc., 21 P.3d 797, 802 (Cal. 2001) (finding posters and t-shirts "expressive works and not an advertisement for or endorsement of a product").

67. Thomas McCarthy endorses a categorical approach that denies any First Amendment consideration to sellers of celebrity merchandise. 1 MCCARTHY, supra note 4, $\S 7: 20$ ("Utilitarian merchandise is not the common medium for socially significant 'messages.'"). But see Dougherty, supra note 65, at 70 (contending that merchandise should receive full First Amendment protection, in part because "[t]here is no way to express an opinion or an emotion or to convey information about a celebrity without identifying that celebrity"). Dougherty clearly has the right side in this debate. While there is certainly celebrity merchandise that conveys no message at all, it is easy to think of celebrity merchandise that conveys a very clear political message. If "Fuck the Draft" is protected speech, see Cohen v. California, 403 U.S. 15 (1971), why should "Screw Khomeini" (a bumper sticker for sale during the 1980 Iran hostage crisis) be any different? Further, even uses that don't include an explicit message about the celebrity are still communicating support for, attraction to, or irony concerning that individual-all speech of the sort the First Amendment protects.

68. Of course, competition may suffer only if a particular celebrity image is sufficiently popular to give its exclusive licensee power over price. But the vigor with which celebrities litigate merchandise claims suggests that they think they are getting some 
The problem is even worse when people use a celebrity's name or image in ways that are critical of the celebrity. It is unreasonable to expect that an individual will license to another the right to criticize or make fun of him. ${ }^{69}$ And there is no question that such parodies and critiques are precisely the sort of speech we want to encourage. While one could say that the celebrity is losing control over his identity, few would suggest that the right of publicity should give celebrities that much control. A strong version of the merchandising right would prevent these desirable uses.

Courts have by and large disregarded these concerns in merchandising cases. While they have recognized speech interests in cases involving news reporting, biography, film, and certain forms of art, ${ }^{70}$ most courts dismiss any suggestion that the sale of celebrity-oriented merchandise brings a public benefit that should weigh into the balance in analyzing right of publicity claims. Even when they give lip service to speech concerns, they generally find them insufficient to counter the interest of celebrities in protecting their identities.

The California Supreme Court's decision in Comedy III Productions, Inc. v. Gary Saderup, Inc. ${ }^{71}$ is illustrative. Gary Saderup, an artist specializing in charcoal sketches of celebrities, sold t-shirts and posters featuring his drawing of the Three Stooges. When the assignee of the deceased actors' right of publicity filed suit, Saderup defended on the ground that the t-shirts were art protected by the First Amendment. While the court gave a good deal of attention to the First Amendment argument, ${ }^{72}$ it ultimately found it wanting. The method the court chose for addressing Saderup's speech interests typifies the skeptical attitude of courts toward celebrity merchandise. After considering a variety of possible approaches to the First Amendment concerns, the court settled on a "transformative use test" modeled loosely on the first factor of copyright fair use analysis: ${ }^{73}$

Another way of stating the inquiry is whether the celebrity likeness is one of the "raw materials" from which an original work is synthesized, or whether the depiction or imitation of the celebrity is the very sum and substance of the

economic value out of such control.

69. It is for this reason that copyright law generally treats parodies as fair use. See, e.g., Campbell v. Acuff-Rose Music, Inc., 510 U.S. 569 (1994); cf. Robert P. Merges, Are You Making Fun of Me?: Notes on Market Failure and the Parody Defense in Copyright, 21 AIPLA Q.J. 305 (1993); Richard A. Posner, When Is Parody Fair Use?, 21 J. LEGAL STUD. 67,71 (1992) (suggesting that parody should be protected up to the point that it serves as a market substitute for the original).

70. See Restatement (Third) of Unfair Competition § 47 (1995) (“[U]se 'for purposes of trade' does not ordinarily include the use of a person's identity in news reporting, commentary, entertainment, works of fiction or nonfiction, or in advertising that is incidental to such uses.").

71. 21 P.3d 797 (Cal. 2001).

72. Id. at $802-11$.

73. See infra notes 120-33 and accompanying text. 
work in question. We ask, in other words, whether a product containing a celebrity's likeness is so transformed that it has become primarily the defendant's own expression rather than the celebrity's likeness. And when we use the word "expression," we mean expression of something other than the likeness of the celebrity.

As Jay Dougherty has persuasively argued, ${ }^{75}$ the transformative use test "is a slender, effervescent wall to protect freedom of expression" in the merchandising context. ${ }^{76}$ It will arguably protect most parodies and other critical uses of celebrity identities and may insulate some artistic portrayals that radically alter the celebrity's look. ${ }^{77}$ But for portrayals that seek accuracy rather than distortion, that seek to pay tribute rather than to criticize, the transformative use test will rarely provide a defense against a right of publicity claim.

The Saderup court and others like it, then, essentially establish a presumption that celebrities have an absolute right to the economic value of their identity, subject only to special First Amendment concerns that will rarely apply in a merchandising case. The courts, in other words, assume the legitimacy of a potent right of publicity that will generally outweigh any speech interests of sellers or buyers of celebrity merchandise. As we discuss below, there is good reason to question that assumption and to demand that courts tie the right of publicity more directly to an identifiable normative goal before attempting to balance the relative interests of the celebrity and the public in merchandising cases.

\section{Evocation}

A second type of problematic case is one in which an advertiser evokes, without directly employing, a celebrity identity for commercial purpose. In the classic example, Vanna White won a suit against Samsung for running an ad that featured a robot turning letters on the Wheel of Fortune set. ${ }^{78}$ While

74. Saderup, 21 P.3d at 809 (emphasis added).

75. Dougherty, supra note 65.

76. Id. at 32; see also Eugene Volokh, Freedom of Speech and the Right of Publicity, 40 Hous. L. REV. 903, 913-25 (2003) (criticizing transformative use test as inadequate to protect speech interests in right of publicity cases).

77. The court offered Andy Warhol's silkscreens as the type of celebrity portrayals that "may well" satisfy the transformative test. See Saderup, 21 P.3d at 811 ("Through distortion and the careful manipulation of context, Warhol was able to convey a message that went beyond the commercial exploitation of celebrity images and became a form of ironic social comment on the dehumanization of celebrity itself."). But in fact there is little difference between Warhol's depictions and Saderup's, except that Warhol is already a recognized artist. Were he working as a beginning artist today and sued by the estate of Marilyn Monroe, it is likely that he would lose a right of publicity case under the California Supreme Court standard.

78. White v. Samsung Elecs. Am., Inc., 971 F.2d 1395 (9th Cir. 1992). For a fuller discussion of White and other cases involving evocation of celebrity identity, see Stacey L. 
acknowledging that Samsung did not directly make use of White's name or likeness, the Ninth Circuit nonetheless held that her allegations supported a right of publicity claim. "The right of publicity," the court held, "does not require that appropriations of identity be accomplished through particular means to be actionable." ${ }^{79}$ Indeed, by limiting the right to particular types of appropriation, "we would not only weaken the right but effectively eviscerate it" because "[t]he identities of the most popular celebrities are not only the most attractive for advertisers, but also the easiest to evoke without resorting to obvious means such as name, likeness, or voice." 80 By evoking White's image, the court held, Samsung had exploited the value of White's celebrity, and therefore it should pay. ${ }^{81}$

As we have discussed elsewhere, a strong evocation right comes at a significant cost to the public. ${ }^{82}$ Speakers have an interest in evoking common cultural symbols to convey themes or ideas uniquely associated with them. ${ }^{83}$ Even if it makes sense to limit advertisers' use of particular, identifiable features of a celebrity's persona, extending the right of publicity beyond those concrete features will inevitably chill speech. Advertisers may well avoid themes, dress, or décor that a particular celebrity has popularized, for fear of raising her ire. Celebrities or their families may seek to stop portrayals they don't like in movies, books, or the media. ${ }^{84}$ And the owners of legitimate IP rights - such as television programmers - may hesitate to license their content for fear that one of their actors will sue. ${ }^{85}$ The problem is exacerbated when the image the celebrity seeks to appropriate is created in whole or in part by another, as in the Wendt and White cases. The personality the court assigns to the celebrity in those cases is not simply the celebrity's own image, but an amalgam of the contributions of writers, cinematographers, and fellow actors.

The reasoning of the Ninth Circuit in White resembles the rationale of the merchandising cases in an important way. In both situations, the courts appear to be assuming that celebrities have a presumptive entitlement to the economic

Dogan, An Exclusive Right To Evoke, 44 B.C. L. REV. 291, 303-08 (2003).

79. White, 971 F.2d at 1398.

80. Id. at 1399 .

81. Id.; see also Landham v. Lewis Galoob Toys, Inc., 227 F.3d 619, 624 (6th Cir. 2000) (announcing that the right of publicity "is now generally understood to cover anything that suggests the plaintiff's personal identity").

82. See Dogan, supra note 78, at 316-18.

83. Id. at 316. See generally Dreyfuss, supra note 52, at 397.

84. See, e.g., Maritote v. Desilu Prods., Inc., 345 F.2d 418 (7th Cir. 1965) (suit by the heirs of Al Capone seeking to stop the making of The Untouchables); Chris Newton, Lubbock Can't Use Holly Name in Music Festival, Widow Says, Austin Am.-STATESman, June 18, 1999, at B11 (noting Buddy Holly's heirs objecting to the use of his name on a music festival).

85. E.g., Wendt v. Host Int'1, Inc., 125 F.3d 806, 809 (9th Cir. 1997) (allowing right of publicity claim by "Cheers" actors against airport bar that acquired a license from the "Cheers" copyright holder to feature the show's characters as part of its décor). 
value of their personas and a right to complain about any use that captures part of that economic value, unless some special First Amendment considerations apply. The outcome of both types of cases depends critically upon the correctness of that assumption, because any change in the weight of the celebrities' interests must affect the overall balance between the interests of celebrities and the interests of those who would like to use - or to buy - their identities in products and ads. We turn, then, to the theoretical justifications for a strong, property-like right of publicity.

\section{THE USUAL EXPLANATIONS}

Commentators, and those courts that have chosen to consider the question, have cast about for years for a persuasive justification for the publicity right. ${ }^{86}$ The need for a normative account is critical, not only to explain why we have the right, but also to understand its scope and weigh it against the kinds of competing concerns discussed above. Most of the explanations offered fall into one of three categories: the moral or natural rights story; the exhaustion or allocative-efficiency account; and the incentive-based rationale. In recent years, the incentive-based rationale has increasingly taken hold, with courts and commentators looking to copyright law in an attempt to validate and give shape to the publicity right. While each of these explanations has some superficial appeal, they all break down under scrutiny. ${ }^{87}$ In this Part, we briefly discuss the problems with the moral and allocative-efficiency explanations and then explain why the current gravitation toward copyright law is both misguided and troubling. ${ }^{88}$

\section{A. Moral Rights}

A moral rights thread has always run through the right of publicity. To some extent, this inevitably results from the law's roots in the right to privacy, which an early court described as "recognized intuitively, consciousness being the witness that can be called to establish its existence." 89 Courts consistently

86. Some have given up, concluding that "the right of publicity is both hard to object to and hard to support. It is then pointless to debate in general terms whether the right ought to exist at all." Westfall \& Landau, supra note 52, at 122 . We are inclined to agree with them that focusing on the contours of the right is more productive, and indeed that is what we attempt in the balance of this Article, though we think that cannot effectively be done without some understanding of why the right exists in the first place.

87. $C f$. Restatement (ThiRd) OF Unfair COMPeTition $\S 46$ cmt. c (1995) (questioning existing rationales for the right of publicity).

88. Numerous scholars have written comprehensive and persuasive critiques of each of these theories, and we offer only an abridged version here. For more thorough examinations, see Dougherty, supra note 65, at 62-71; Madow, supra note 14, at 178-238; McKenna, supra note 8 .

89. Pavesich v. New Eng. Life Ins. Co., 50 S.E. 68, 70 (Ga. 1905); see also id. ("A 
viewed the privacy right as a kind of moral imperative, a liberty interest against "manifest unfairness," private citizens.

The transition from personal-tort-based right of privacy to economically oriented right of publicity, however, required a shift in the nature-if not an abandonment - of the moral imperative. While courts and commentators continued to rely upon moral rights reasoning, ${ }^{91}$ their rationale changed from a theory of personal liberty to a labor-based moral right. In particular, they turned to the flip sides of the Lockean coin: the asserted right to the fruits of one's labor and protection against unjust enrichment. The celebrity, the argument goes, has rights to the fruits of her labor and, at the very least, has the right to prevent others from taking those fruits for their own personal gain.

As others have pointed out, ${ }^{92}$ however, neither the labor nor the unjust enrichment theory can support a right of publicity that reserves to a celebrity all the economic value of her identity. From a labor perspective, the value of a celebrity persona rarely owes itself exclusively - or even primarily - to the efforts of the celebrity. Others - writers who craft the celebrity's dramatic roles, ${ }^{93}$ agents who pluck her from obscurity, studios and marketing directors who shape her public image, even devotees who fan the flames of her popularity - play a role in creating the value of a celebrity. Given the lack of direct relation between celebrity labor and celebrity value, it makes little sense to assign the full economic value of the persona to the celebrity based on a labor rights theory.

Nor can a theory of human dignity justify the right of publicity. Even assuming that human dignity includes the right to prevent people from making true statements about you to sell a commercial product, ${ }^{94}$ it fits uneasily with a

right of privacy in matters purely private is therefore derived from natural law.").

90. Sheldon W. Halpern, The Right of Publicity: Maturation of an Independent Right Protecting the Associative Value of Personality, 46 HASTINGS L.J. 853, 873 (1995).

91. See, e.g., id. at 871; Roberta Rosenthal Kwall, Fame, 73 IND. L.J. 1, 57 (1997); J. Thomas McCarthy, The Human Persona as Commercial Property: The Right of Publicity, 19 COLUM.-VLA J.L. \& ARTS 129, 140-41 (1995).

92. See sources cited supra note 88 .

93. E.g., Wendt v. Host Int'l, Inc., 125 F.3d 806, 809 (9th Cir. 1997) (involving conflict between creators of "Cheers" series and actors who played characters in the series).

94. See Edward J. Bloustein, Privacy as an Aspect of Human Dignity: An Answer to Dean Prosser, 39 N.Y.U. L. REV. 962, 989 (1964).

A human dignity approach may well support a more narrowly drawn right of publicity focused on uses that falsely suggest celebrity endorsement of commercial products. E.g., Waits v. Frito-Lay, Inc., 978 F.2d 1093 (9th Cir. 1992) (allowing a claim by Tom Waits against Frito-Lay for sound-alike advertisement that suggested Waits's endorsement of Dorito product). See generally Roberta Rosenthal Kwall, The Right of Publicity vs. the First Amendment: A Property and Liability Rule Analysis, 70 IND. L.J. 47, 73 (1994) ("Waits' feelings of anger and embarrassment were particularly pronounced given his strong public stand against doing any type of commercial endorsements."). This approach, which harkens back to the early right of publicity cases, recognizes both the economic and reputational 
right of publicity that is only rarely about preventing such uses and almost always about maximizing the celebrity's profit from them. ${ }^{95}$ The fact that people who claim ownership rights over their personalities are willing to sell their dignity for a fairly low price in many cases ${ }^{96}$ should make us skeptical of a claim that this is really a form of paternalism designed at protecting individuals from commercialization. It may in fact have the opposite effect: as David Troutt warns, "unchecked propertization portends a diminution of personal identity." 97

The unjust enrichment argument ${ }^{98}$ fares no better. The moral claim for ownership of publicity rights presumes that someone must have property rights in the value of a celebrity persona. ${ }^{99}$ If that presumption is correct, then it might make sense to assign rights to the celebrity rather than some third party. But before assigning property rights in this way, we should test the basic presumption that property rights are appropriate in the first place. The very existence of a right, in other words, requires some justification: in a market economy it is not reasonable to simply assume that someone must own the right to compete in particular ways. ${ }^{100}$ But the unjust enrichment rationale makes

injury that can result from the false association of a celebrity with commercial products that she did not endorse. It does not, however, justify the current form of the right of publicity, which has in fact moved away from concerns about human dignity and toward maximization of economic returns. And it is worth noting that such a dignitary claim would largely parallel the scope of the right justified by the search-cost rationale.

95. See Jacoby \& Zimmerman, supra note 48, at 1322 (noting that the right of publicity is treated as a property rather than a personal right); Richard A. Posner, The Right of Privacy, 12 GA. L. REV. 393, 411 (1978) (noting that an alienable property right would be a strange response to problems with commercialization of identity).

96. For example, students have sold their bodies to banks for use as billboards and tattooed logos onto their skin. See, e.g., David Dante Troutt, A Portrait of the Trademark as a Black Man: Intellectual Property, Commodification, and Redescription, 38 U.C. DAVIS L. REV. 1141, 1143-44 (2005) (describing these instances).

97. Id. at 1146 .

98. See 1 McCARThy, supra note 4, § 2:2; Harry Kalven, Jr., Privacy in Tort LawWere Warren and Brandeis Wrong?, 31 LAW \& CONTEMP. ProBS. 326, 331 (1966).

99. For critiques of this assumption, see Dogan \& Lemley, Merchandising Right, supra note 11, at 478-81 (critiquing unjust enrichment justification for merchandising rights in the trademark context); Mark A. Lemley, Ex Ante Versus Ex Post Justifications for Intellectual Property, 71 U. CHI. L. REV. 129, 144-47 (2004) [hereinafter Lemley, Ex Ante]; Diane Leenheer Zimmerman, Fitting Publicity Rights into Intellectual Property and Free Speech Theory: Sam, You Made the Pants Too Long!, 10 DePaUl-LCA J. ART. \& ENT. L. \& POL'Y 283, 307 (2000) [hereinafter Zimmerman, Pants].

100. As Ralph Brown put it, "competition is copying." Ralph S. Brown, The Joys of Copyright, 30 J. COPYRIGHT SOC’Y 477, 481 (1983); see also Robert C. Denicola, Freedom To Copy, 108 YALE L.J. 1661, 1661 (1999) ("[L]aws that restrain copying... restrain competition."). See generally Peter Jaffey, Merchandising and the Law of Trade Marks, 3 INTELL. PROP. Q. 240 (1998) (noting that trademark law does not support a general merchandising right).

Alice Haemmerli advocates a Kantian approach to the publicity right. Alice Haemmerli, Whose Who? The Case for a Kantian Right of Publicity, 49 DuKE L.J. 383 (1999). But Haemmerli, too, falls victim to the erroneous assumption that someone must have rights in 
just such an assumption. As such, it fails to provide a standalone explanation for the publicity right.

The labor and unjust enrichment rationales also fail to explain uses that the law treats as beyond the celebrity's control. If a celebrity has a right to appropriate the full value of her persona and to prevent others from profiting from the use of her name, that right logically would seem to extend to control over references in the for-profit news media, documentaries, biographies, and a variety of other creative works to which the right of publicity does not extend even today. A moral rights theory needs to be able to explain not just why we grant certain rights, but also why we don't grant others. ${ }^{101}$

Indeed, we can just as easily imagine a moral entitlement claim to be free from right of publicity claims. ${ }^{102}$ Such an argument would run something like this: In a free society, people have a right to make truthful statements about other people, at least so long as those statements don't invade another's privacy. ${ }^{103}$ Further, in a capitalist economy, people should not be punished for making money from something they have a right to do. A right of publicity interferes with this fundamental moral right and is therefore unjustified. We make this argument not to demonstrate its truth, but to demonstrate the ultimate indeterminacy of claims based on moral right. How is a court to choose between "blind appeals" to these competing moral principles? ${ }^{104}$

One way a court might do so is to look to social norms of behavior as dictating morality. But here the moral entitlement claim for publicity rights

an individual's persona:

As to whether a person should be able to claim a property right in the use of her objectified identity, there is no logical reason why she should not and every reason why she should: if one's own image, for example, is treated as an object capable of "being yours or mine," why should it not be claimed by the person who is its natural source?

Id. at 418 (emphasis added) (footnote omitted). Haemmerli bases her justification for the right of publicity on human autonomy, but she offers no reason to privilege the autonomy of the celebrity protected by the right of publicity over the autonomy of speakers such a right would curtail.

101. See Mark F. Grady, A Positive Economic Theory of the Right of Publicity, 1 UCLA ENT. L. REV. 97, 109 (1994) (noting that unjust enrichment approaches cannot explain limits on liability). One might view the moral rights theory as normative rather than descriptive, and argue that the failure to give celebrities control over their portrayal in the news media is an oversight that needs to be rectified. But if so, moral rights theorists need to be forthright about the consequences of their approach.

102. See, e.g., Madow, supra note 14, at 138-46 (describing speech interests of those who make use of celebrity images).

103. This right has been contested at various times in history. See, e.g., Lawrence Lessig, Free(ing) Culture for Remix, 2004 UTAH L. REV. 961, 961 (noting claims in the early days of the camera that no one could take another's picture without permission). Nonetheless, it seems well established as a general moral proposition today, at least in the United States. See, e.g., Dwyer v. Am. Express Co., 652 N.E.2d 1351 (Ill. App. Ct. 1995) (refusing to recognize a right to control sale of mailing list including personal name); Shibley v. Time, Inc., 341 N.E.2d 337 (Ohio Ct. App. 1975) (same).

104. Cardtoons, L.C. v. Major League Baseball Players Ass'n, 95 F.3d 959, 975 (10th Cir. 1996) (rejecting "blind appeals to first principles" in the right of publicity). 
runs into a more serious problem. A broad right of publicity runs counter to historical assumptions and social norms in the United States and around the world. Throughout history, artists and commentators have invoked, interpreted, and merchandised famous countenances without repercussion. ${ }^{105}$ And with good reason: such uses promote important speech interests of both the speaker and recipients of the information. Ironically enough, to the extent a moral norm against such practices is evolving, it is deriving directly from United States law. ${ }^{106}$ This makes it doubly important that United States courts think critically about the theoretical basis for this evolving social norm and set the right of publicity on a coherent, defensible course.

\section{B. Allocative Efficiency}

While most courts have relied on moral rights or incentive-based theories, a set of economic commentators increasingly relies on an allocative-efficiency argument to support the right of publicity. This is a slight modification of the classic tragedy of the commons argument: unless we centralize control over valuable resources such as fame, they will suffer from overuse and ultimately lose all their value. ${ }^{107}$

Despite its superficial appeal, however, the commons argument breaks down in the context of information markets, such as markets in personal images. ${ }^{108}$ Certainly, granting exclusive rights over celebrity images will reduce the use of those images, increase their price, and therefore make more money for the rights-holders. ${ }^{109}$ But as a general matter, such underproduction

105. See, e.g., David Bollier, Brand Name Bullies: The Quest To Own AND Control Culture 131 (2005) (noting that Benjamin Franklin and other Framers did not object to the use of their images for commercial purposes).

106. Traditionally there has been no right of publicity in Commonwealth countries. See, e.g., 1 MCCARTHY, supra note 4, $\S 6: 155-6: 156$. European scholars frequently look to United States law as a model for publicity rights law. See, e.g., Klink, supra note 5, at 387 ("[Fifty] years of daily practice have proven the advantages of separate publicity rights in the United States.").

107. See, e.g., Grady, supra note 101, at 110-26 (arguing that a right of publicity is necessary to coordinate a market for a celebrity's name and prevent rent dissipation through overuse); $c f$. William M. Landes \& Richard A. Posner, Indefinitely Renewable Copyright, 70 U. CHI. L. REV. 471, 485 (2003) (claiming that one justification for the right of publicity is "to prevent the premature exhaustion of the commercial value of the celebrity's name or likeness").

108. Lemley has developed this argument fully in Lemley, Ex Ante, supra note 99, and portions of this Part are adapted from that article.

109. See Kenneth J. Arrow, Economic Welfare and the Allocation of Resources for Invention, in THE RATE AND DIRECTION OF INVENTIVE ACTIVITY 609, 617 (1962) ("[I]nventive activity is supported by using the invention to create property rights; precisely to the extent that it is successful, there is an underutilitzation of the information."); Harold Smith Reeves, Property in Cyberspace, 63 U. CHI. L. REV. 761, 785 (1996) ("With respect to informational resources, then, the existence of any legal boundaries will decrease the potential availability of informational resources on the Internet."). Empirical research has 
and owner enrichment are anathema to competition in a market economy. Restricting access to information goods makes sense if, but only if, the information would in fact be underproduced or overdistributed in the absence of a property right. In other words, the commons-based justification for the right of publicity depends on proof that there is in fact a tragedy of the commons in celebrity images.

As Lemley has pointed out elsewhere, however, the basic notion of a tragedy of the information commons rests on a flawed understanding of the nature of information. Unlike finite natural resources, which can be depleted by overuse, information is what economists call nonrivalrous: ${ }^{110}$ it simply cannot be "used up." 111 To the contrary, the proliferation of celebrity images-like the distribution of other forms of information - only extends the reach of the images, making them more available to those who wish to use and enjoy them. And these people's use and enjoyment causes positive externalities that have ripple effects throughout the economy. ${ }^{112}$ An individual baseball card might be worth more money if cards of that player were deliberately made rare, and so sellers (or more likely resellers) of that card might increase their total profit. But do we really think society as a whole would be better off if only one company could make baseball cards and only rich adults could obtain cards featuring famous baseball players?

In the right of publicity context, advocates of the commons argument have taken a slightly different tack. Rather than arguing that the celebrity image itself will be depleted by overuse, some courts and commentators worry that

indeed shown some evidence that the growth in the right of publicity reduced the willingness of advertisers to use celebrity endorsements, presumably by raising the price and the risk associated with marginal uses. See Tom Bellamore, Is Vanna White Really So Dangerous? An Empirical Assessment of the Impact of White v. Samsung Electronics on Parody and Advertising, 11 U. MiAmi BUS. L. REV. 53, 82-94 (2003).

110. See, e.g., Robert P. Merges et al., Intellectual Property in the New Technological Age 16 (3d ed. 2003); Peter S. Menell, An Analysis of the Scope of Copyright Protection for Application Programs, 41 STAN. L. ReV. 1045, 1059 (1989).

111. See, e.g., James Boyle, The Second Enclosure Movement and the Construction of the Public Domain, 66 LAW \& CONTEMP. ProBS. 33, 41 (2003); Niva Elkin-Koren, Copyrights in Cyberspace-Rights Without Laws?, 73 CHI.-KENT L. REV. 1155, 1191-92 (1998); Carol M. Rose, Romans, Roads and Romantic Creators: Traditions of Public Property in the Information Age, 66 LAW \& CONTEMP. Probs. 89, 90 (2003).

112. See Reeves, supra note 109 , at 785 . "The result is that rather than a tragedy, an information commons is a 'comedy' in which everyone benefits." Lemley, Ex Ante, supra note 99, at 143; see also BoLLIER, supra note 105, at 36 (collecting references to the "comedy" or "cornucopia" or "inverse" commons that occurs with nondepletable information); Benjamin G. Damstedt, Limiting Locke: A Natural Law Justification for the Fair Use Doctrine, 112 YALE L.J. 1179, 1182-83 (2003) (suggesting that it is waste by underuse rather than depletion by overuse with which intellectual property theorists should be concerned). See generally Carol Rose, The Comedy of the Commons: Custom, Commerce, and Inherently Public Property, 53 U. CHI. L. REV. 711 (1986) (developing notion of "the comedy of the commons" to describe situations in which increased public access to a resource causes positive externalities that bring an overall benefit to society). 
the value of the image to its owner will decline with overuse. ${ }^{113}$ Yet this instinct, too, is at base anti-market. In a market economy, we hope and expect that competing producers will increase their production until prices drop to marginal cost. ${ }^{114}$ It defies logic to set policy goals that aim to insulate producers from this very form of competition. We might have to accept such a market distortion if we thought that the control we granted over price would encourage new creation, as we believe in patent and copyright law, but there is no such justification for the right of publicity.

\section{Incentive Models and Copyright}

A final justification offered for the right of publicity is that the grant of such control is needed to encourage investment in the development of a public persona. This theory is related to the efficiency claim discussed in the last Part, but while that argument focused on efficient management after the fact, the incentive claim focuses on efficient efforts to create a persona ex ante. In recent decades, defenders of publicity rights have increasingly gravitated toward this incentive model, often borrowing directly from copyright law. ${ }^{115}$ The Supreme Court ushered in this trend in Zacchini v. Scripps-Howard Broadcasting Co., ${ }^{116}$ its first and only decision addressing a right of publicity claim. Zacchini involved a performer's publicity claim against a television news broadcaster that taped and aired footage of his entire act. The Court held that Ohio's recognition of a right of publicity claim in the case did not offend the First Amendment, because of the important state interest in preserving performers' incentives:

[T]he State's interest in permitting a "right of publicity" is in protecting the proprietary interest of the individual in his act in part to encourage such entertainment. ... [T] he State's interest is closely analogous to the goals of patent and copyright law, focusing on the right of the individual to reap the

113. See supra note 107 and accompanying text (discussing this argument). But $c f$. Dogan, supra note 78 (pointing out that celebrities may have incentives to optimize their uses regardless of the rights we grant them to control the uses of others).

114. Lemley explains:

Economists have a term for markets in which different providers keep selling goods with less and less value until the point is reached where it would cost more to produce a good than the public is willing to pay for it. We call such a market "perfectly competitive," and we have thought for at least three centuries (since Adam Smith) that it is a good thing. Lemley, Ex Ante, supra note 99, at 144.

115. See, e.g., Comedy III Prods., Inc. v. Gary Saderup, Inc., 21 P.3d 797, 804 (Cal. 2001) ("The right of publicity, like copyright, protects a form of intellectual property that society deems to have some social utility."); Randall T.E. Coyne, Toward a Modified Fair Use Defense in Right of Publicity Cases, 29 WM. \& MARY L. REV. 781, 812 (1988) (" $[\mathrm{C}]$ opyright is the proper analogy for defining the scope of publicity rights."); Tina J. Ham, Note, The Right of Publicity: Finding a Balance in the Fair Use Doctrine-Hoffman v. Capital Cities/ABC, Inc., 36 U.C. DAVIS L. REV. 543 (2003); Kevin S. Marks, Comment, An Assessment of the Copyright Model in Right of Publicity Cases, 70 CAL. L. REV. 786 (1982).

116. 433 U.S. 562 (1977). 
reward of his endeavors and having little to do with protecting feelings or reputation. 117

Zacchini was probably the right of publicity case closest in nature to common law copyright, since the defendant took not just an image or identity but an entire performance. ${ }^{118}$ Since Zacchini, courts have looked to copyright principles both to justify the right of publicity and to strike a balance between the interests of celebrities and the public. As justification, courts contend that the right of publicity promotes investment in creative work much in the way that copyright law promotes investment in original expression. ${ }^{119}$ As a balancing mechanism, courts look to copyright's fair use doctrine, in whole or in part, to accommodate the competing interests of celebrities and those who would like to use their personas in some form of speech. In Saderup, for example, the California Supreme Court opted against a wholesale importation of fair use in the right of publicity context, but viewed one factor - the transformative nature of the use-as clearly relevant:

When artistic expression takes the form of a literal depiction or imitation of a celebrity for commercial gain, directly trespassing on the right of publicity without adding significant expression beyond that trespass, the state law interest in protecting the fruits of artistic labor outweighs the expressive interests of the imitative artist. 120

The copyright analogy, however, is both misleading and dangerous. First, and most importantly, the economic rationale for copyright law-that market failure would occur in the absence of the legal right-simply does not apply in the right of publicity context. ${ }^{121}$ As Diane Zimmerman points out, "[n]ot a shred of empirical data exists to show that [celebrities] would ... invest less energy and talent" in becoming famous without a publicity right, ${ }^{122}$ particularly since the law provides protection primarily to those who are "already

117. Id. at 573; see also id. at 576 ("[The right of publicity] provides an economic incentive for [a performer] to make the investment required to produce a performance of interest to the public.").

118. We are indebted to Paul Goldstein for this point.

119. See, e.g., White v. Samsung Elecs. Am., Inc., 971 F.2d 1395 (9th Cir. 1992); Saderup, 21 P.3d at 805. But see Cardtoons, L.C. v. Major League Baseball Players Ass'n, 95 F.3d 959, 974 (10th Cir. 1996) ("Thus, while publicity rights may provide some incentive for creativity and achievement, the magnitude and importance of that incentive has been exaggerated.").

120. Saderup, 21 P.3d at 808 (footnote omitted).

121. See Wendy J. Gordon, Asymmetric Market Failure and Prisoner's Dilemma in Intellectual Property, 17 U. DAYTON L. ReV. 853 (1992).

122. Zimmerman, Pants, supra note 99, at 306; see also Michael A. Carrier, Cabining Intellectual Property Through a Property Paradigm, 54 DuKe L.J. 1, $43-44$ (2004) (offering multiple reasons why a right of publicity isn't necessary to create incentives to fame); Rochelle Cooper Dreyfuss, We Are Symbols and Inhabit Symbols, So Should We Be Paying Rent? Deconstructing the Lanham Act and Rights of Publicity, 20 COLUM.-VLA J.L. \& ARTS 123, 144 (1996); Richard A. Posner, Misappropriation: A Dirge, 40 Hous. L. Rev. 621, 634 (2003) (dismissing the incentive story, but endorsing the congestion/overuse story). 
handsomely compensated" and for whom additional protection is unlikely to provide much marginal incentive. ${ }^{123}$ Even if celebrities would make such an additional investment, it is not at all clear that society should want to encourage fame for fame's sake. ${ }^{124}$ Unlike copyright law-which aims to promote the production of valuable works of authorship that enhance the quality of discourse and understanding in our society - the right of publicity rewards those who, with luck, hard work, or accident of birth, happen to join the ranks of the famous. ${ }^{125}$ Because the right of publicity does not encourage the production of any identifiable value, the copyright analogy cannot support the right. $^{126}$

The problems with the analogy only intensify when courts map specific copyright doctrines into right of publicity cases. For example, courts and commentators often seek to apply copyright's fair use doctrine to the right of publicity. ${ }^{127}$ The fair use doctrine in copyright law is designed to balance two specific (if elusive) values: the need to preserve incentives for creative expression and the need for the public to access and employ existing expressive works in speech-enhancing ways. The structure of fair use analysis attempts (albeit imperfectly) to weigh these competing values in the context of a particular act of copying. It makes sense, at least in theory, to compare the relative import of a copier's contributions against the impact that such copying might have on the production of future creative works. In the right of publicity context, the flaws in the utilitarian model make the analogous equation nonsensical. How can a court evaluate whether a particular use of celebrity identity is likely to have a negative impact on future incentives for celebrities to invest in their creative activity, given the complete absence of a proven incentive relationship in the first place?

123. Cardtoons, 95 F.3d at 974

124. Cf. Steven J. Hoffman, Limitations on the Right of Publicity, 28 Bull. COPYRIGHT SOC'Y 111, 120 (1980) (arguing that celebrity endorsements may have a "net social disutility").

125. See McKenna, supra note 8.

126. See, e.g., 1 MCCARTHY, supra note $4, \S 2: 6$ ("The right of publicity in such instances must find support in other rationales ....").

127. See, e.g., Saderup, 21 P.3d at 807-08; Stephen R. Barnett, The Right of Publicity Versus Free Speech in Advertising: Some Counterpoints to Professor McCarthy, 18 Hastings Comm. \& EnT. L.J. 593, 604 (1996); Pamela Samuelson, Reviving Zacchini: Analyzing First Amendment Defenses in Right of Publicity and Copyright Cases, 57 Tul. L. REV. 836, 915 (1983) (proposing a "slightly modified version of the fair use copyright doctrine" for the right of publicity); Douglas G. Baird, Note, Human Cannonballs and the First Amendment: Zacchini v. Scripps-Howard Broadcasting Co., 30 STAN. L. ReV. 1185, 1206-07 (1978); Douglas J. Ellis, Comment, The Right of Publicity and the First Amendment: A Comment on Why Celebrity Parodies Are Fair Game for Fair Use, 64 U. CIN. L. REV. 575, 612 (1996). But see Kwall, supra note 94, at 58 (rejecting copyright's fair use framework); Roberta Rosenthal Kwall, Is Independence Day Dawning for the Right of Publicity?, 17 U.C. DAVIS L. REV. 191, 232 (1983) (noting problems with applying copyright's fair use analysis). 
Rather than persuading courts to abandon the analogy to copyright and fair use, these snags have led courts to borrow only some, but not all, of the fair use factors in right of publicity cases. The Saderup court, for example, chose the first fair use factor, making everything turn on the transformative nature of the defendant's use. ${ }^{128}$ But such an approach ignores the fact that the fair use calculus reflects a subtle and complex balancing of multiple interests that makes sense only in combination. Even nontransformative uses, for example, should be given free rein when they pose little threat to copyright incentives. ${ }^{129}$ Absent some parallel analysis of the effect of a use on the core values of right of publicity law, the fair use analogy loses its balance and becomes affirmatively misleading.

Even if we could map a fair use counterpart for the right of publicity, it is not at all clear that we would do well to look to copyright as our model. Despite its rational roots and facially balanced ambitions, copyright's fair use doctrine has morphed into a largely incoherent area of law that hardly deserves emulation. ${ }^{130}$ And courts have used the existence of this doctrine to justify a hands-off approach to copyright law under the First Amendment, leading to a skewed balance in favor of copyright holders and against free speech. ${ }^{131}$ The use of concepts such as "transformative use" inevitably leads courts to engage in content-based analysis, favoring certain types of speech over others without any compelling justification. The California Supreme Court's discussion of the relative artistic value of Gary Saderup's charcoal sketches as compared to Andy Warhol's "transformative" art is but one example. ${ }^{132}$ To the extent that copyright's fair use doctrine has led to such value-laden balancing, speech concerns should lead courts to resist exporting it into the right of publicity context.

The copyright analogy, in short, fails to support the right of publicity and leads to a skewed and inaccurate portrayal of the relative interests of celebrities and the public. ${ }^{133}$ Like the moral rights and allocative-efficiency explanations,

128. Saderup, 21 P.3d at 808; see also Winter v. D.C. Comics, 69 P.3d 473, 475 (Cal. 2003).

129. E.g., Sony Corp. of Am. v. Universal City Studios, 464 U.S. 417 (1984).

130. 2 MCCARTHY, supra note $4, \S 8: 38$ ("[T] he copyright concept of 'fair use' is one of the last places to look to find clarity and predictability."); Dougherty, supra note 65, at 28; John Shepard Wiley, Jr., Copyright at the School of Patent, 58 U. CHI. L. REV. 119 (1991). But see Coyne, supra note 115, at 814-15 (arguing that the copyright model will "inject uniformity and predictability" into the right of publicity, a claim of which we are skeptical).

131. See Eldred v. Ashcroft, 537 U.S. 186 (2003); Mark A. Lemley \& Eugene Volokh, Freedom of Speech and Injunctions in Intellectual Property Cases, 48 DuKE L.J. 147 (1998); cf. Jennifer E. Rothman, Initial Interest Confusion: Standing at the Crossroads of Trademark Law, 27 CARDOZo L. REv. 105, 150-51 (2005) (contending that the constitutional roots of copyright law explain its general immunity from First Amendment scrutiny, and that this hands-off approach will not extend into the trademark context).

132. See supra note 77 .

133. It may present another problem as well—copyright preemption. Federal copyright law generally preempts state rights equivalent to copyright. 17 U.S.C. $\S 301$ (2006). 
it ultimately fails to explain or justify the existing form of publicity right.

\section{TRADEMARK LAW: A BETTER ANALOGY}

To date, then, a reasonable and persuasive justification for the right of publicity has been sorely lacking. The usual rationales - moral rights, allocative efficiency, and incentives - provide inadequate support for any right of publicity, let alone the current muscular form of the right. And while the historic justification of protecting privacy is a perfectly legitimate justification, it does not actually support the right in its current scope. ${ }^{134}$ Courts and commentators variously cite each of these justifications but do not (and arguably cannot) apply them in any consistent way. Worse, they often simply assume an unassailable right of publicity, without even considering whether the right as they have defined it promotes any legitimate policy goal.

Yet there is a compelling explanation for a right of publicity, albeit one that differs quite substantially from the scope of the right as it currently exists. The structure and content of trademark law provide a theoretical justification for a bounded right of publicity. ${ }^{135}$ Trademark law offers a far better lens than copyright law with which to understand what is going on in the right of publicity cases. It also offers what previous theories have not-a reason to protect publicity rights. Trademark law isn't perfect, but it is coherent. More important, it is by far the closest analogy to the right of publicity. Both laws are concerned not with the encouragement of new creation, like other forms of IP rights, but with the protection of names in the context of commercial uses. Trademark law is designed to protect the integrity of a mark's meaning by preventing uses of the mark that confuse consumers or, for famous marks, uses that interfere with consumers' mental association between mark and good. That goal also seems a legitimate justification for the right of publicity. If people are misled by the use of a celebrity name or likeness, both they and the celebrity are injured. Given that the only ones who benefit do so through deceit, such use almost certainly creates a net social harm.

Defining the right of publicity in copyright terms could lead to a finding that it is preempted altogether. See Baltimore Orioles, Inc. v. Major League Baseball Players Ass'n, 805 F.2d 663, 674 (7th Cir. 1986) (finding that copyright law preempted a right of publicity claim). Courts that have rejected preemption have pointed to the differences between the right of publicity and copyright law. See Toney v. L'Oreal USA, Inc., 406 F.3d 905, 910 (7th Cir. 2005). For an argument for broad preemption of the right of publicity based on the Supremacy Clause, rather than 17 U.S.C. $§ 301$ (2006), see Jennifer E. Rothman, Copyright Preemption and the Right of Publicity, 36 U.C. DAVIS L. REV. 199 (2002); see also Wendt v. Host Int'l, Inc., 197 F.3d 1284, 1288 (9th Cir. 1999) (Kozinski, J., dissenting from denial of rehearing en banc).

134. See infra Part III.B.

135. Cf. ETW Corp. v. Jireh Publ'g, Inc., 332 F.3d 915, 924 (6th Cir. 2003) (noting that " $[\mathrm{t}]$ he elements of a Lanham Act false endorsement claim are similar to the elements of a right of publicity claim"). 
The trademark analogy provides not only a reason to protect publicity rights, but also a way to understand the limits on those rights. Having a logical, coherent explanation for the right of publicity and an established body of case law elaborating that explanation allows us to measure the elements, limitations, and scope of the right of publicity against an established yardstick. If the rationale for a right of publicity claim follows from a parallel trademark claim, the substantive scope of that claim should probably also track the trademark claim. If it does not, it is worth asking why. Unfortunately, as we will see, while the vast majority of right of publicity cases fit within the established framework of trademark law, they apply the doctrine in ways that diverge significantly from what the trademark analogy would suggest.

\section{A. Explaining Right of Publicity Cases Using the Trademark Framework}

In this Part, we discuss each of the four major prongs of trademark law and their rationales, explain how each serves as an apt description of a significant body of right of publicity cases, and then explore the ways in which those right of publicity cases have been applied without the justifications or limitations that circumscribe the corresponding right in trademark law.

\section{Likelihood of confusion}

Trademark law does not give trademark owners property rights over words, even when those words are fanciful. Rather, traditional trademark doctrine protects mark owners only against the use of the same or a similar mark as a brand, generally by competitors, in circumstances likely to confuse the consuming public. ${ }^{136}$ The rationale for such protection is straightforward. The use of brands permits companies to build goodwill in their products, reducing the cost to consumers of finding a product with the quality and characteristics they are looking for and permitting manufacturers to reap a return on investments in product quality. ${ }^{137}$ If competitors could confuse consumers into thinking they were buying a brand-name product when they weren't, they could capture sales by manufacturing cheaper products and deceiving consumers into

136. See, e.g., Two Pesos, Inc. v. Taco Cabana, Inc., 505 U.S. 763, 767-68 (1992) ("The Lanham Act was intended to make actionable the deceptive and misleading use of marks and to protect persons engaged in commerce against unfair competition.") (internal quotations omitted); Ralph S. Brown, Jr., Advertising and the Public Interest: Legal Protection of Trade Symbols, 57 YaLe L.J. 1165, 1185 (1948); Mark A. Lemley, The Modern Lanham Act and the Death of Common Sense, 108 YALE L.J. 1687 (1999) [hereinafter Lemley, Modern Lanham Act]; Glynn S. Lunney, Jr., Trademark Monopolies, 48 EMORY L.J. 367, 391 (1999). The dilution and merchandising cases are exceptions to this basic principle, and we discuss them separately below in Parts III.A.2 and III.A.4, respectively.

137. For a further elaboration of this search-cost rationale, see our discussion in Dogan \& Lemley, Trademarks and Consumer Search Costs, supra note 11. 
purchasing them. Consumer expectations would be dashed, and producers would no longer have the incentive to invest in quality products.

The consumer confusion rationale is central to a variety of legal doctrines in trademark law. Consumer reactions are consulted to determine whether a mark is protectable at all, whether a once-protected mark should be denied protection because it is generic, whether a defendant's mark is sufficiently similar to be infringing, and what remedy is appropriate if it is infringing. ${ }^{138}$ Consumer reactions also affect other doctrines, from who is entitled to priority of trademark use to whether it is permissible to parody a mark. ${ }^{139}$

While the classic case of consumer confusion-counterfeiting - involves consumers who are confused about the source of the products they buy, trademark protection is not limited to cases of source confusion. Courts have found infringement even where two related products do not directly compete, because consumers might assume that the maker of one also makes the other and blame the trademark owner for any defect in the other good. ${ }^{140}$ Courts have also found actionable confusion to occur after the sale or during the initial capture of a consumer's interest. ${ }^{141}$ Most relevant for our purposes, trademark law prevents others from confusing consumers as to the affiliation or sponsorship between the trademark owner and the defendant, even if no one thinks the trademark owner actually supplied the defendant's products. Even when consumers don't believe that the trademark owner is the one selling the

138. See, e.g., Zatarain's Inc. v. Oak Grove Smokehouse, Inc., 698 F.2d 786 (5th Cir. 1983) (stating that consumer surveys are important to determine protectability of descriptive marks); AMF Inc. v. Sleekcraft Boats, 599 F.2d 341 (9th Cir. 1979) (regarding consumer surveys important to find infringement); King-Seeley Thermos Co. v. Aladdin Indus., 321 F.2d 577, 579 (2d Cir. 1963) (asserting that views of public are determinative of genericness).

139. See, e.g., Hormel Foods Corp. v. Jim Henson Prods., Inc., 73 F.3d 497 (2d Cir. 1996) (confusion relevant to legality of parody); Cliffs Notes, Inc. v. Bantam Doubleday Dell Publ'g Group, 886 F.2d 490 (2d Cir. 1989) (same); Perma Ceram Enters. v. Preco Indus., 23 U.S.P.Q.2d (BNA) 1134 (T.T.A.B. 1992) (noting that priority of use of a descriptive mark depends on consumer conclusions about meaning of mark).

140. $A M F, 599$ F.2d at 341; 4 J. Thomas MCCarthy, MCCARThy on Trademarks AND UNFAIR COMPETITION $§ 24: 2$ (4th ed. 2005) (noting that trademark law has expanded to control uses of a trademark on different but related goods "such that the ordinary buyer would be likely to think there was some connection or sponsorship between the producers or sellers of goods bearing a similar mark, even though the goods were non-competitive"); see also Robert G. Bone, Enforcement Costs and Trademark Puzzles, 90 VA. L. ReV. 2099 (2004).

141. See, e.g., Brookfield Commc'ns v. W. Coast Entm't Corp., 174 F.3d 1036 (9th Cir. 1999) (initial-interest confusion actionable even where dispelled before purchase); Mastercrafters Clock \& Radio Co. v. Vacheron \& Constantin-LeCoultre Watches, Inc., 221 F.2d 464, 466 (2d Cir. 1955) (holding that confusion by people who see the product after purchase is actionable); Dogan \& Lemley, Merchandising Right, supra note 11, at 491-92 (discussing postsale confusion); Alex Kozinski, Trademarks Unplugged, 68 N.Y.U. L. REV. 960, 964 (1993) (same). More recent cases have cut back on initial-interest confusion, however. See, e.g., Lamparello v. Falwell, 420 F.3d 309 (4th Cir. 2005); Bosley Med. Inst. v. Kremer, 403 F.3d 672 (9th Cir. 2005). 
product, the use of a similar trademark may still confuse them by causing them to believe that the trademark owner is affiliated with or sponsors the infringer's products. For example, suppose that a company that sells soup uses the trade symbol of the Chicago White Sox on its soup cans. Presumably, the White Sox do not sell soup, and no reasonable consumer would be likely to conclude that she was in fact buying White Sox soup. But consumers might well conclude that the soup maker was somehow affiliated with the White Sox or that one group had agreed to sponsor the other. This confusion as to affiliation is actionable under the Lanham Act, assuming the other requirements for protecting a mark are met. ${ }^{142}$ Trademark law, then, comes into play whenever consumers would presume affiliation, sponsorship, or other association between the trademark holder and another party selling goods under a similar mark. ${ }^{143}$ The law no longer limits itself to cases of "passing off" goods as manufactured or produced by the trademark holder.

Because celebrities, unlike trademark owners, don't typically sell products themselves, confusion about affiliation or sponsorship is most directly analogous to right of publicity cases. ${ }^{144}$ In a number of right of publicity cases, a defendant used a celebrity's name, image, or identity in an advertisement in a way that suggested to viewers that the celebrity was endorsing the product in some way, or at least was paid to lend her name to the product. Thus, in Midler v. Ford Motor Co. ${ }^{145}$ Ford hired an impersonator to copy the vocal style of singer Bette Midler for its advertisement. Midler, who refuses as a matter of principle to endorse products or lend her songs to advertisements, sued for infringement of her right of publicity. The court ruled in her favor, in significant part because the defendant was gaining an advantage in the marketplace by misleading consumers into believing she had endorsed their

142. Confusion as to affiliation or sponsorship is only expressly addressed in section 43(a) of the Lanham Act, which applies to unregistered marks. But at least one commentator has suggested quite reasonably that the protections afforded to unregistered marks under section 43(a) also apply to registered marks, whether under section 32 of the Lanham Act or under section 43(a). See Jay Dratler, JR., Intellectual Property Law: Commercial, CREATIVE, AND INDUSTRIAL PROPERTY $\S 10.01[1][\mathrm{b}][\mathrm{i}]$ (2d ed. 2005).

143. Congress codified this expansion in the Lanham Act, providing a cause of action against any person who falsely implies an "affiliation, connection, or association" with a trademark holder, or causes confusion "as to the origin, sponsorship, or approval of his or her goods, services, or commercial activities. . ." 45 U.S.C. § 1125(a) (2006).

144. See Grant v. Esquire, Inc., 367 F. Supp. 876, 879 (S.D.N.Y. 1973) (calling the right of publicity "somewhat akin" to trademark law); Hogan v. A.S. Barnes \& Co., 114 U.S.P.Q. 314, 320 (Pa. Ct. C.P. 1957) (describing the right of publicity as "unfair competition under another label"); Richard Ausness, The Right of Publicity: A "Haystack in a Hurricane," 55 TEMP. L.Q. 977, 1054 (1982) (“Analytically, the right of publicity could be classified as a form of unfair competition."); James Treece, Commercial Exploitation of Names, Likenesses, and Personal Histories, 51 TEX. L. REV. 637, 647 (1973) (noting the role of the right of publicity in preventing consumer deception).

145. 849 F.2d 460 (9th Cir. 1988). 
products. ${ }^{146}$ Many other right of publicity cases take this form as well-Waits v. Frito-Lay ${ }^{147}$ and Motschenbacher v. R.J. Reynolds, ${ }^{148}$ for example. ${ }^{149}$ Some courts have gone so far as to suggest that this is the basic theory behind the right of publicity: "The basis of a right of publicity claim concerns the message - whether the plaintiff endorses, or appears to endorse the product in question." 150

The use of a celebrity's name or likeness to falsely suggest she is affiliated with or has sponsored the defendant's goods seems problematic for the same reasons as false designation of origin in the trademark context, and it provides a valid justification for the right of publicity. Two significant caveats to that conclusion are in order, however. First, celebrities might be able to obtain the same benefits by using the Lanham Act itself, without the need for a separate right of publicity. While the registration of a personal name as a trademark is rare, ${ }^{151}$ section $43(\mathrm{a})$ of the Lanham Act provides similar protections to unregistered marks or trade names, and a number of courts have applied it to celebrity false endorsement claims. ${ }^{152}$

146. Id. at 463 .

147. 978 F.2d 1093 (9th Cir. 1992).

148. 498 F.2d 821 (9th Cir. 1974).

149. See also Henley v. Dillard Dep't Stores, 46 F. Supp. 2d 587, 589 (N.D. Tex. 1999) (preventing defendant from selling shirts using the phrase "this is Don's henley" because consumers would think musician Don Henley was connected with the shirts); Nat'l Bank of Commerce v. Shaklee Corp., 503 F. Supp. 533, 541-42 (W.D. Tex. 1980) (preventing use of "Hints from Heloise" in ways that misled consumers into assuming an association with the defendant); Palmer v. Schonhorn Enters., 232 A.2d 458 (N.J. Super. Ct. Ch. Div. 1967) (preventing defendant from using the name of golfer Arnold Palmer to sell a golf board game)

150. Toney v. L'Oreal USA, Inc., 406 F.3d 905, 910 (7th Cir. 2005).

151. There are some personal names registered as trademarks. O.J. Simpson sought to register his name, for example, only to have it opposed by someone who claimed the use of his name on products was immoral or scandalous. Ritchie v. Simpson, 170 F.3d 1092 (Fed. Cir. 1999); $c f$. Abdul-Jabbar v. Gen. Motors Corp., 85 F.3d 407, 411 (9th Cir. 1996) (holding that basketball star Kareem Abdul-Jabbar had not abandoned his birth name, Lew Alcindor, and reasoning that "[a] proper name thus cannot be deemed 'abandoned' throughout its possessor's life, despite his failure to use it ...").

152. See, e.g., Landham v. Lewis Galoob Toys, Inc., 227 F.3d 619, 626 (6th Cir. 2000) ("A false designation of origin claim brought by an entertainer under $\S 43$ (a) of the Lanham Act in a case such as this is equivalent to a false association endorsement claim . . and the 'mark' at issue is the plaintiff's identity."); Waits v. Frito-Lay, Inc., 978 F.2d 1093 (9th Cir. 1992). This interpretation arguably stretches the Lanham Act, which ordinarily requires a party to use a term "in the ordinary course of trade," affixed to goods or in the sale or advertising of goods and services, in order to qualify for trademark protection. 15 U.S.C. $\S$ 1051(a) (2006) (requiring use "in commerce"); id. § 1127 (defining use in commerce). The stretch is a plausible one, however, because false celebrity endorsements distort the information marketplace in the same way as other forms of sponsorship confusion. $C f$. Laura A. Heymann, The Birth of the Authornym: Authorship, Pseudonymity, and Trademark Law, 80 Notre Dame L. Rev. 1377, 1434-44 (2005) (contending that "reverse passing off" doctrine of trademark law should protect against confusion that results when one party falsely claims authorship of another's work). 
The second caveat flows from the nature of the trademark analogy. Consumer confusion justifies the establishment of a right of publicity only to the extent that there actually is consumer confusion. If a defendant uses a celebrity's name or likeness in a way that evokes her name but does not confuse consumers, this justification will not apply. ${ }^{153}$ Unfortunately, courts in right of publicity cases generally do not ask whether consumers are in fact confused. ${ }^{154}$ Publicity cases rarely include surveys, for example. A significant segment of the right of publicity cases, and even the subset of endorsement cases, finds no justification under this approach. Examples of cases in which the right of publicity has been applied to "endorsements" in the absence of any possible consumer confusion include Carson v. Here's Johnny Portable Toilets, ${ }^{155}$ where the defendant used talk show host Johnny Carson's tag line "Heeeere's Johnny!" for a portable toilet; Spike Lee's successful suit against Viacom enjoining the use of the name "Spike TV"; 156 and White v. Samsung, where the defendant used a robot in a blond wig that Wheel of Fortune host Vanna White claimed evoked her persona. ${ }^{157}$ There is no question that the defendants in some of these cases sought to evoke the plaintiff in the minds of their customers, and it is likely that they succeeded. But it is extremely unlikely that anyone was confused or believed the celebrity had agreed to the use. ${ }^{158}$

153. As Judge Rich explained in a trademark case:

The very fact of calling to mind may indicate that the mind is distinguishing, rather than being confused by, the two marks .... Seeing a yellow traffic light immediately "calls to mind" the green that has gone and the red that is to come, or vice versa; that does not mean that confusion is being caused.

In re Ferrero, 479 F.2d 1395, 1397 (C.C.P.A. 1973). Courts have thus commonly allowed imitation of famous trade dress by private label retailers seeking to point out the similarities between their product and a well-known brand. See, e.g., Conopco, Inc. v. May Dep't Stores Co., 46 F.3d 1556, 1565 (Fed. Cir. 1994) (finding no infringement when a private label retailer "packages its product in a manner to make it clear to the consumer that the product is similar to the national brand, and is intended for the same purposes"); Am. Home Prods. Corp. v. Barr Labs., Inc., 656 F. Supp. 1058, 1070 (D.N.J. 1987) ("The fact that one mark may bring another mark to mind does not in itself establish likelihood of confusion as to source."), aff'd, 834 F.2d 368 (3d Cir. 1987).

154. See, e.g., Rogers v. Grimaldi, 875 F.2d 994, 1004 (2d Cir. 1989) (“"T] he right of publicity, unlike the Lanham Act, has no likelihood of confusion requirement . . . ."); Univ. of Notre Dame du Lac v. J.C. Gourmet Food Imps. Co., 703 F.2d 1372, 1376 (Fed. Cir. 1983) (finding that the right of publicity can be violated even without a likelihood of confusion); Restatement (THIRD) UNFAIR COMPETITION $\S 46 \mathrm{cmt}$. b (1995) ("Proof of deception or consumer confusion is not required ....").

155. 698 F.2d 831 (6th Cir. 1983).

156. BOLLIER, supra note 105, at 134 (reporting the case and subsequent settlement).

157. For criticism of the White decision, see, for example, Paul J. Heald, Filling Two Gaps in the Restatement (Third) of Unfair Competition: Mixed-Use Trademarks and the Problem With Vanna, 47 S.C. L. ReV. 783, 806 (1995); David S. Welkowitz, Catching Smoke, Nailing Jell-O to a Wall: The Vanna White Case and the Limits of Celebrity Rights, 3 J. INTELl. PROP. L. 67 (1995). What it says about Vanna White that her persona can apparently be captured by a robot is beyond the scope of this Article.

158. Astoundingly, the Ninth Circuit in the White case reversed summary judgment for the defendant on the Lanham Act claim as well, holding that "a jury could reasonably 
Other cases are closer. In Motschenbacher, for example, the defendant used a picture of auto racer Lothar Motschenbacher's car in its cigarette advertisement. ${ }^{159}$ While the evidence suggested the car was recognizable as his, it is far from clear that an appreciable number of consumers would assume that he had endorsed the product in that case merely because a picture of his car appeared in an advertisement. It's not impossible that they would, ${ }^{160}$ but in order to know whether the right of publicity should apply, we would want to know what consumers thought, just as we would in a trademark case presenting the same theory of false endorsement.

The requirement of confusion is an important limitation on this rationale for the right of publicity, just as it is in the ordinary trademark case. This explanation will not ordinarily justify a postmortem right of publicity, for example. ${ }^{161}$ Plaintiffs who seek to prevent nonconfusing uses will need to find other justifications. Unfortunately, the failure of right of publicity courts to explicitly consider the confusion rationale in these cases leads them to stray from imposing this requirement consistently. ${ }^{162}$ The result is that numerous people bring lawsuits along the lines of Vanna White's, alleging not confusion but merely recognition. ${ }^{163}$ Here too the claims may have an analogy to the

conclude that beneath the surface humor... lay an intent to persuade consumers that celebrity Vanna White... was endorsing Samsung products." White v. Samsung Elecs. Am., Inc., 971 F.2d 1395, 1401 (9th Cir. 1992). The confusion claim strikes us as inconceivable; even in the Ninth Circuit, summary judgment is appropriate in trademark cases when the plaintiff's claim defies common sense. $C f$. Sykes Lab., Inc. v. Kalvin, 610 F. Supp. 849, 861 (C.D. Cal. 1985) ("As a matter of law, and of common sense, the use of this bottle could not cause a likelihood of confusion either at the critical point of sale or afterwards.").

159. Motschenbacher v. R.J. Reynolds Tobacco Co., 498 F.2d 821 (9th Cir. 1974).

160. Indeed, there is evidence that some viewers understood that the car was his and inferred that he was endorsing the product. $I d$. at 822,827 .

161. See, e.g., Cairns v. Franklin Mint Co., 292 F.3d 1139, 1155 (9th Cir. 2002) (finding no confusion in the use of Princess Diana memorabilia after her death in a trademark case). We can imagine only limited circumstances in which a confusion-based right of publicity might survive death, such as the use of digital technology to make it seem that an actor appeared in a movie in which he did not. See, e.g., Joseph J. Beard, Casting Call at Forest Lawn: The Digital Resurrection of Deceased Entertainers-A 21st Century Challenge for Intellectual Property Law, 8 High Tech. L.J. 101, 146-70 (1993). On the problems with a postmortem right of publicity, see, for example, William A. Drennan, Wills, Trusts, Schadenfreude, and the Wild, Wacky Right of Publicity: Exploring the Enforceability of Dead-Hand Restrictions, 58 ARK. L. REV. 43 (2005); Westfall \& Landau, supra note 52, at 122 .

162. This may not be an accident. Some courts, most notably those in California, reject any effort to limit the right of publicity to situations of false endorsement. See, e.g., Eastwood v. Superior Court, 198 Cal. Rptr. 342, 348 (Ct. App. 1983). But as we noted in Part II, supra, this begs the question of what does justify the right of publicity in California.

163. See White v. Samsung Elecs. Am., Inc., 989 F.2d 1512, 1515 n.18 (9th Cir. 1993) (Kozinski, J., dissenting from denial of rehearing en banc) (citing examples of suits by Adam West claiming the right to remind people of Batman - watch out Christian Bale, George Clooney, and Michael Keaton - by the portrayer of "Vampira" against the portrayer of "Elvira, Mistress of the Dark"; by Guy Lombardo against those who lead big bands on New 
recent mutation of "initial-interest confusion" in many courts to make illegal any attraction of interest using a trademark. We have critiqued this expansion elsewhere, ${ }^{164}$ for now, it is worth noting the parallels not only between the legitimate aspects of trademark law and the endorsement-based right of publicity cases but also between overzealous trademark decisions and zeal in the right of publicity cases. Trademark courts have recently cut back on initialinterest confusion, ${ }^{165}$ and it is well past time for the right of publicity courts to do the same.

\section{Dilution}

In exceptional cases, trademark law will prevent the use of a mark even in the absence of consumer confusion. The doctrine of trademark dilution, long resident in certain state statutes and a feature of the Lanham Act since 1996, gives the owners of sufficiently famous marks protection against other producers' uses of those marks even for unrelated goods, provided that the defendant is using the term as a mark for its own goods rather than merely as a reference to the trademark owner's goods. ${ }^{166}$

Some have criticized dilution law for treating trademarks as property. ${ }^{167}$ But like traditional trademark law, dilution properly understood is targeted at reducing consumer search costs. Dilution takes two forms: blurring the distinctive significance of a mark by associating it with lots of different products, and tarnishing the image of the mark by associating it with

Year's Eve; and by Uri Geller against those who claim to use mind power to bend spoons).

164. Dogan \& Lemley, Trademarks and Consumer Search Costs, supra note 11, at 819-28; see also Eric Goldman, Deregulating Relevancy in Internet Trademark Law, 54 EMORY L.J. 507 (2005) (criticizing expansion of initial-interest confusion doctrine in the Internet context); Rothman, supra note 131, at 179-91 (advocating wholesale abandonment of initial-interest confusion doctrine).

165. See supra note 141.

166. For a general discussion of trademark dilution, see DAVID Welkowitz, TRADEMARK DiLUTION (2002). As currently drafted, the dilution statute requires proof of "commercial use in commerce." 15 U.S.C. $§ 1125(\mathrm{c})(1)$ (2006). The legislative history makes it clear that the term "commercial use" is intended to limit dilution cases to ones in which the defendant engages in "commercial speech" as that term is understood in First Amendment law. H.R. Rep. No. 104-374, at 8 (1995). Commercial speech is speech that "does 'no more than propose a commercial transaction." Bolger v. Youngs Drug Prods. Corp., 463 U.S. 60, 66 (1983) (quoting Va. Pharmacy Bd. v. Va. Citizens Consumer Council, Inc., 425 U.S. 748, 762 n.24 (1976)); see also Hoffman v. Capital Cities/ABC, Inc., 255 F.3d 1180, 1184 (9th Cir. 2001) (applying the doctrine to a right of publicity case).

Legislation pending in Congress at this writing would change the dilution statute in significant ways. See H.R. 683, 109th Cong. (2005). That bill would remove the rather artless phrase "commercial use in commerce" but would require that the defendant make use of the plaintiff"s mark "as a mark or trade name." This should incorporate the same limits as the existing commercial speech requirement.

167. See, e.g., Kenneth L. Port, The "Unnatural" Expansion of Trademark Rights: Is a Federal Dilution Statute Necessary?, 85 TRADEMARK REP. 525, 552 (1995). 
unwholesome products. Both blurring and tarnishment can make it somewhat more difficult for consumers to associate a famous mark with its owner. Blurring takes a formerly unique mark (say, Exxon), which consumers can associate with the mark owner without any necessary context, and applies it to unrelated products - say, Exxon pianos or Exxon carpets. Even if the consumer understands that these different Exxons are unrelated, the proliferation of Exxon-marked products may make it more difficult for consumers to figure out which company is responsible for any particular product. (Quick: What does Delta sell?). ${ }^{168}$ Tarnishment occurs when a defendant uses a mark on unrelated goods and services of shoddy quality or of an offensive nature. Even if consumers understand that the marks are unrelated, their subconscious associations with the mark may be more negative as a result of the tarnishing uses. As we have written elsewhere:

For example, if a defendant sells Toyota brand pornography, those who encounter the use may think less highly of the Toyota brand name because they subconsciously associate it with pornography, even if they understand that the car company did not itself sponsor the materials. By contrast, an irate consumer wearing a t-shirt that says "Toyota sucks" or shows a cartoon character urinating on the Ford logo isn't tarnishing the brand in the sense the law cares about. These protest uses do not interfere with consumers' association between the logo and the company through some subconscious pollution. If anything, they strengthen the mental connection between trademark holder and mark, albeit in a way the company might not like. ${ }^{169}$

These latter are not actionable under the dilution law. ${ }^{170}$

The rationale for dilution might seem to apply to a range of right of publicity cases in which a defendant uses a famous celebrity's name in ways that do not confuse consumers. ${ }^{171}$ And indeed it is possible to think of some right of publicity cases that fit into the dilution categories, particularly tarnishment. One possible example is the "Velvet Elvis" bar enjoined by the

168. Different Deltas provide airline services, dental health insurance, telecommunications, faucets, and a variety of other goods and services.

169. Dogan \& Lemley, Merchandising Right, supra note 11, at 494.

170. To be sure, courts applying the tarnishment doctrine have sometimes used it to target criticism or derogatory speech about the trademark owner, a result that finds little justification in the search-cost rationale. See, e.g., Deere \& Co. v. MTD Prods., Inc., 41 F.3d 39 (2d Cir. 1994). Those courts are clearly mistaken in their understanding of the doctrine, however, and most courts properly distinguish the two. See, e.g., Mattel Inc. v. Walking Mountain Prods., 353 F.3d 792 (9th Cir. 2003); MasterCard Int'l Inc. v. Nader 2000 Primary Comm. Inc., 70 U.S.P.Q. 2d 1046, 1052-53 (S.D.N.Y. 2004).

171. See Allen v. Men's World Outlet, Inc., 679 F. Supp. 360, 366-67 (S.D.N.Y. 1988) (stating that dilution is "equivalent" to infringement on the right of publicity); Sarah M. Konsky, Publicity Dilution: A Proposal for Protecting Publicity Rights, 21 SANTA Clara COMPUTER \& HigH TECH. L.J. 347 (2005) (proposing protection of publicity rights under conditions similar to trademark dilution). But see 4 MCCARTHY, supra note 4, § 28.02[1] (rejecting the analogy). Still, even McCarthy goes on to call dilution "the point at which trademark law approaches most closely to the boundary line of the right of publicity." Id. $\S$ 5.11 . 
Fifth Circuit in Elvis Presley Enterprises, Inc. v. Capece. ${ }^{172}$ Elvis is apparently dead, ${ }^{173}$ and it seems unlikely that anyone thinks he or his estate has endorsed the bar in question. But suppose he were alive. The bar was designed to be kitschy, and if the bar is particularly tawdry one could imagine that even the image of Elvis might be undermined in the minds of consumers as a result. Similarly, the adoption of a celebrity's name as a brand for the sale of goods ("Angelina Jolie"-brand pianos or "George Bush"-brand carpets) might constitute blurring if repeated uses of this sort would make it difficult for consumers to know without context whether it was the celebrity or a trademarked business that was being referred to. ${ }^{174} \mathrm{~A}$ recent case involving the use of Rosa Parks's name as the title of a song whose lyrics had nothing to do with Rosa Parks, except for an isolated reference to competing rappers moving "to the back of the bus," might qualify as blurring the image of the celebrity. ${ }^{175}$ For the same reasons we think dilution should be prevented in trademark law, a true case of dilution of a personal name should also be enjoined.

But neither blurring nor tarnishment of personal names seems likely to be a common occurrence. At the outset, a dilution theory would require proof of real fame-not some notoriety, but true celebrity. ${ }^{176}$ That won't be so hard to prove; most right of publicity cases have in fact been brought by celebrities, and there seems little incentive to try to associate one's products with people who aren't particularly famous. Indeed, the true uniqueness of name that the

172. 141 F.3d 188 (5th Cir. 1998). home.").

173. But see Men IN BLACK (Sony Pictures 1997) ("No, Elvis is not dead. He just went

174. Such uses have occasionally occurred throughout history. Madow reports examples including "Benjamin Franklin" handkerchiefs and "Sarah Bernhardt" candy. Madow, supra note 14, at 149-52.

175. Parks v. LaFace Records, 329 F.3d 437 (6th Cir. 2003). Critical to the court's conclusion is the fact that the song has nothing in fact to do with Rosa Parks. Id. at 452. Songs that talk about a celebrity should be free to use the celebrity's name, because the use is reinforcing and not diluting the connection to the celebrity. Thus, Bree Sharp should not face liability for singing "David Duchovny, why won't you love me?" BREE SHARP, A CHEAP AND EVIL GIRL (Trauma Records 1998). Similarly, a record label could use singer Axl Rose's likeness in connection with a rerelease of music by Rose's previous band, Hollywood Rose, because the use had artistic relevance to the content of the material being advertised. Cleopatra Records v. Bailey, No. CV 04-3120 GAF, 2005 U.S. Dist. LEXIS 32780, at *3 (C.D. Cal. May 23, 2005); cf. Mattel, Inc. v. MCA Records, Inc., 296 F.3d 894 (9th Cir. 2002) (holding that the band Aqua could use the title "Barbie Girl" for a song about Barbie without running afoul of trademark law).

A closer case is one where the celebrity's name may also have some connection to the product being sold, as in the case of "Here's Johnny" portable toilets, Carson v. Here's Johnny Portable Toilets, 698 F.2d 831 (6th Cir. 1983), or a leg-shaving gel named after football player Elroy Hirsch's nickname "Crazylegs," Hirsch v. S.C. Johnson \& Son, Inc., 280 N.W. 2d 129 (Wis. 1979).

176. J. Thomas McCarthy, Proving a Trademark Has Been Diluted: Theories or Facts?, 41 Hous. L. REV. 713, 731-33 (2004) (noting the importance of the fame requirement and the problems with relying on a theory of local or niche fame). 
rationale of dilution seems to require ${ }^{177}$ is more likely to be present in a personal name than in a trademark, since trademarks are often descriptive or arbitrary English words with many different meanings. ${ }^{178}$

Blurring or tarnishment will be harder to demonstrate. Blurring is particularly unlikely in the context of the right of publicity. The general effect of the use of a celebrity's name is not to distract an audience from the connection between the name and the celebrity, but to reinforce it. George Bush might not like the use of his name for pianos or carpets, and if people think he is endorsing the carpets the law will forbid that use, but it seems unlikely that people will be slower or less likely to recognize "George Bush" as the name of a U.S. President because they must mentally sort through different commercial uses. ${ }^{179}$ And if the use of a name, like the use of a mark, reinforces rather than undermines an audience's connection between the name and the celebrity, it will not constitute dilution. A dilution rationale, then, does not offer right of publicity plaintiffs carte blanche to prevent nonconfusing uses of their name, but a much more limited right to prevent the use of their name as a trademark in a way that does not suggest a connection of affiliation between the names. ${ }^{180}$

177. On the importance of a unique connection between a word and a mark, see generally William G. Barber, A "Rational" Approach for Analyzing Dilution Claims: The Three Hallmarks of True Trademark Dilution, 33 AIPLA Q.J. 25, 29-30 (2005); Barton Beebe, The Semiotic Analysis of Trademark Law, 51 UCLA L. REV. 621, 682-83 (2004); Vincent Chiappetta, Trademarks: More than Meets the Eye, 2003 U. ILL. J.L. TECH. \& POL'Y 35; Sara Stadler Nelson, The Wages of Ubiquity in Trademark Law, 88 IowA L. REV. 731 (2003).

178. See McCarthy, supra note 176, at $738-39$ (noting examples of arguably famous marks that nonetheless share multiple meanings, including Amazon, Tide, Ford, Time, Shell, Bell, and Polo). It is possible to imagine circumstances in which two famous people share the same name, so that it is already diluted. But it's not likely to be a common occurrence.

179. A number of commentators have discussed psychological literature suggesting that referential uses of the sort the dilution statute forbids may actually strengthen rather than undermine consumer associations with the brands they are evoking. See generally Beebe, supra note 177; Goldman, supra note 164. If that is true, there may be no harm from blurring at all, and it is only tarnishment that presents a true dilution problem. $C f$. McCarthy, supra note 176, at 745-47 (questioning whether blurring causes any real harm). But see Thomas R. Lee, Demystifying Dilution, 84 B.U. L. Rev. 859, 920 (2004) (noting that blurring by its nature cannot actually be observed, but may nonetheless be inferred).

180. Ironically, the Rosa Parks case, which has been much criticized, see Lisa Tomiko Blackburn, Title Blanding: How the Lanham Act Strips Artistic Expression from Song Titles, 22 CARdozo Arts \& ENT. L.J. 837 (2005); Christine Haight Farley, Judging Art, 79 Tul. L. REV. 805, 828-29, 851-52 (2005); Mitchell David Greggs, Shakin' It to the Back of the Bus: How Parks v. LaFace Uses the Artistic Relevance Test To Adjudicate Artistic Content, 61 WASH. \& LeE L. REV. 1287 (2004); David Nimmer, The Moral Imperative Against Academic Plagiarism (Without a Moral Right Against Reverse Passing Off), 54 DePAul L. ReV. 1 (2004), may be one of the few examples of a use that might blur the distinctiveness of a name by using it to draw attention to unrelated goods. See RESTATEMENT (THIRD) OF UNFAIR COMPETITION $\S 47 \mathrm{cmt}$. c ("Use of another's identity in a novel, play, or motion picture is ... not ordinarily an infringement... [unless] the name or likeness is used solely to attract attention to a work that is not related to the identified person ....").

Of course, the fact that the Parks case was correctly decided on right of publicity 


\section{Cybersquatting}

With the development of Internet domain names, some unscrupulous entrepreneurs called "cybersquatters" managed to make a significant profit by registering domain names corresponding to various trademarks and offering to sell them to the trademark owner. Because domain names are rivalrous - the owner of a domain name such as mcdonalds.com can prevent anyone else from using the name - and are allocated on a first-come, first-served basis, there was significant value to being the first to own a domain name. Because users would often try to find a trademark owner by typing [trademark].com into their Internet browsers, at least before the development of accurate search engines around the turn of the millennium, the squatter's interference with that connection obviously raised consumer search costs on the Internet.

Although trademark owners sued on theories of consumer confusion and dilution, and frequently prevailed, ${ }^{181}$ core cybersquatting activity did not fit either category very well. Cybersquatters did not necessarily use the site they owned at all, making it hard to argue that they were confusing consumers. And while famous trademark owners could make a possible blurring argument based on the difficulty of finding the trademark owner's website, ${ }^{182}$ many victims of cybersquatters did not in fact have famous marks. ${ }^{183}$ Congress solved this problem in 1999 by enacting the Anticybersquatting Consumer Protection Act

grounds doesn't mean there is no First Amendment problem with restricting the speech. The First Amendment might step in if the use of Parks's name constituted protected speech rather than merely proposing a commercial transaction. Cf. Mattel, 296 F.3d at 907 (finding full First Amendment protection in the Aqua song "Barbie Girl" because the contents of the song included commentary on Barbie). For detailed discussions of the First Amendment problems raised by the right of publicity, see Barbara A. Burnett, The Property Right of Publicity and the First Amendment: Popular Culture and the Commercial Persona, 3 HofsTRA Prop. L.J. 171 (1990); Ira J. Kaplan, They Can't Take That Away From Me: Protecting Free Trade in Public Images from Right of Publicity Claims, 18 LoY. L.A. ENT. L.J. 37 (1997); Kwall, supra note 94; Lemley \& Volokh, supra note 131, at 224-29; Samuelson, supra note 127; Edgar Sargent, Comment, Right of Publicity Tarnishment and the First Amendment, 73 WASH. L. REV. 223 (1998); Edward C. Wilde, The Scope of Liability Under California's Right of Publicity Statutes: Civil Code Sections 990 and 3344, 5 UCLA ENT. L. REV. 167 (1998).

181. See, e.g., Panavision Int'l v. Toeppen, 141 F.3d 1316 (9th Cir. 1998) (finding infringement by registration of the term "Panavision" by a cybersquatter); Archdiocese of St. Louis v. Internet Entm't Group, 34 F. Supp. 2d 1145 (E.D. Mo. 1999) (finding the term "papalvisit1999.com" to be a famous mark infringed by a pornographer, despite the fact that it had never been used in commerce); Intermatic Inc. v. Toeppen, 947 F. Supp. 1227, 1240 (N.D. Ill. 1996) (finding Intermatic to be a famous mark diluted by cybersquatting).

182. This argument also seems weak, as the domain name is not in fact being used as a mark by the cybersquatter. Tom McCarthy treats the cybersquatting cases as a separate, third type of dilution, 3 MCCARTHY, supra note $4, \S 24: 69.1$, and some courts have followed this approach. See, e.g., Avery Dennison Corp. v. Sumpton, 189 F.3d 868 (9th Cir. 1999).

183. Courts frequently stretched the definition of fame in cybersquatting cases, holding names like "Intermatic" to be famous in a significant portion of the United States. Intermatic, 947 F. Supp. at 1239. 
(ACPA), which targeted the precise conduct engaged in by cybersquatters. ${ }^{184}$ The law focused on bad-faith registration of multiple domain names in hopes of selling them and excluded from its scope registration of a domain name by a defendant who had some legitimate reason to use it, whether for its own trademarked product or to resell or criticize the trademark owner's products. ${ }^{185}$

The same problems that bedevil trademark owners on the Internet also affect celebrities. Cybersquatters have registered personal names as domain names in a number of litigated cases. ${ }^{186}$ The injury to celebrities is the same as the injury to trademark owners: the celebrity cannot communicate with fans using the obvious domain name and may have to pay money to get the name back. ${ }^{187}$ The right of publicity can serve to vindicate the celebrity's interest in such a case. But it is not clear that we need a separate right of publicity to achieve this result. The UDRP does not in fact create a cause of action for celebrities, though panelists have sometimes granted them relief nonetheless. ${ }^{188}$ But the ACPA does contain a right to sue those who cybersquat on personal names, ${ }^{189}$ though its characteristics differ in important respects from the protections provided to trademark owners. The right to control cybersquatting

184. 15 U.S.C. $\S 1125$ (d) (2006). In the same month, ICANN adopted the Uniform Dispute Resolution Procedure (UDRP), which created a quick, cheap dispute resolution procedure. For a list of decisions under the UDRP, see Internet Committee for Assigned Names and Numbers (ICANN), Search Index of Proceedings Under the Uniform DomainName Dispute-Resolution Policy, http://www.icann.org/cgi-bin/udrp/udrp.cgi (last visited Jan. 31, 2006). On the design of the system and its shortcomings, see A. Michael Froomkin, ICANN's "Uniform Dispute Resolution Policy"-Causes and (Partial) Cures, 67 BrooK. L. REv. 605 (2002); Michael Geist, Fair.com? An Examination of the Allegations of Systematic Unfairness in the ICANN UDRP, 27 BROOK. J. INT'L L. 903 (2002); Lawrence R. Helfer \& Graeme B. Dinwoodie, Designing Non-National Systems: The Case of the Uniform Domain Name Dispute Resolution Policy, 43 WM. \& MARY L. ReV. 141 (2001); Elizabeth G. Thornburg, Fast, Cheap, and Out of Control: Lessons from the ICANN Dispute Resolution Process, 6 J. Small \& Emerging BuS. L. 191 (2002). For an argument that the UDRP rendered the ACPA unnecessary, see Suzanna Sherry, Haste Makes Waste: Congress and the Common Law in Cyberspace, 55 VAND. L. REV. 309, 354-56 (2002).

185. 15 U.S.C. $\S 1125(d)(1)(B)(i)(2006)$.

186. See, e.g., Turner v. Fahmi, No. D2002-0251 (WIPO 2002) (tedturner.com); Springsteen v. Burgar, No. D2000-1532 (WIPO 2001) (brucespringsteen.com); Roberts v. Boyd, No. D2000-0210 (WIPO 2000) (juliaroberts.com).

187. Not everyone agrees that this should be a compensable injury even in the trademark context. See Kenneth Port, Trademark Monopolies in the Blue Nowhere, 28 WM. MitChELL L. REV. 1091 (2002). But it does seem an injury of the sort that can interfere with consumer search costs to the extent consumers seek websites by typing in domain names.

188. See Roberts, No. D2000-0210. But see Turner, No. D2002-0251; Springsteen, No. D2000-1532; Diamond v. Goldberg, No. FA0402000237446 (Nat'l Arbitration Forum 2004) (dustindiamond.com). For a discussion of efforts to use the UDRP to protect personal names, see Jacqueline D. Lipton, Beyond Cybersquatting: Taking Domain Name Disputes Past Trademark Policy, 40 WaKe Forest L. ReV. 1361, 1413-35 (2005); Georgette H. Tarnow, WWW.YOURNAME.COM: How Useful Is the Uniform Domain Name Dispute Resolution Policy ("UDRP”) in Protecting Personal Names from Cybersquatters?, 22 J. MARSHALl J. COMPUTER \& INFO. L. 535 (2004).

189. 15 U.S.C. $\S 1129$ (2006). 
on personal names does not require any proof of bad faith, as the trademark anti-cybersquatting provisions do. ${ }^{190}$ But it is also limited to circumstances in which the defendant has a "specific intent to profit from such name by selling the domain name for financial gain to that person or any third party . . .."191 This statute captures pure cases of celebrity cybersquatting, ${ }^{192}$ though cases in which the registration of a domain name is used to mislead visitors will have to be addressed in other ways. In short, while the right of publicity has a legitimate role in preventing cybersquatting, the right doesn't seem necessary to achieve that result in the ordinary case. In this context the Lanham Act already achieves most of what the right of publicity would.

\section{Merchandising}

A final theory diverges from the consumer search-cost rationale for the rest of trademark law, and instead treats the mark itself as a product over which the owner has a property right. This "trademark as property" approach has as its most obvious manifestation the assertion of control over merchandise bearing a trademark. As we have explained elsewhere:

When fans buy t-shirts with the name of their school, team, or rock band, they are almost always buying a product bearing an established mark entitled to some form of trademark protection. ${ }^{193}$ But the mark in these cases is rarely serving the traditional function of a trademark. Rather than indicating something to the consumer about the source or sponsorship of a product, the mark is the product, or at least is a critical part of what makes the product attractive. While the mark may, on occasion, also signal something about the source or sponsorship of the shirt, its function transcends the role of a traditional trademark. Merchandising cases therefore represent a kind of hybrid between product configuration and word-based trademark infringement claims: they generally involve protected marks, but the marks are more product features than brands. ${ }^{194}$

While trademark owners assert a right to control such uses, and there are

190. § 1129(1)(A).

191. Id. For a discussion of the differences, see 2 MCCARTHY, supra note 4, § 7:30.

192. See, e.g., Schmidheiny v. Weber, 285 F. Supp. $2 d 613$ (E.D. Pa. 2003).

193. As we have explained elsewhere:

Typically, the mark has acquired trademark status through use in connection with some other primary activity, such as baseball entertainment services, educational services, or music performance. As such, the mark serves as a source-indicator with respect to these services, and the trademark holder would have the right to prevent use of the mark on similar services or products.

By contrast, in Japan and increasingly in the United States people will sometimes buy tshirts that display either an invented logo (one that doesn't in fact brand a real product) or a random collection of words. The case for merchandising protection for such invented logos is even weaker than for established trademarks.

Dogan \& Lemley, Merchandising Right, supra note 11, at 471-72.

194. Id. 
some cases that grant such a right, ${ }^{195}$ a closer look at the merchandising cases overall suggests that trademark holders may be relying on a proverbial house of cards. ${ }^{196}$ The theoretical case for creating a property right over trademarks is weak in some cases and nonexistent in others. ${ }^{197}$ There is simply no inherent right to be the only one to make money by trading on the value of a trademark. The law permits such "free riding" in numerous cases where the defendant benefits from proximity to the plaintiff's mark, so long as the use does not increase consumer search costs. ${ }^{198}$ The doctrinal case fares no better. As we have shown elsewhere, courts are at best evenly split as to whether a

195. See, e.g., Boston Prof'1 Hockey Ass'n v. Dallas Cap \& Emblem, 510 F.2d 1004, 1012 (5th Cir. 1975); Nat'1 Football League Props. v. Consumer Enters., 327 N.E.2d 242, 247 (Ill. App. Ct. 1975).

196. See Dogan \& Lemley, Merchandising Right, supra note 11, at 472-78.

197. Id. (making that argument).

198. There are numerous examples where we permit free riding on the goodwill of a trademark. See, e.g., Saxlehner v. Wagner, 216 U.S. 375, 380 (1910) (permitting a mineral water producer to use its competitor's mark to identify the product that it was copying; reasoning that as long as the defendants did not create confusion about the real source of their product, they were free "to tell the public what they are doing, and to get whatever share they can in the popularity of the [trademarked product] by advertising that they are trying to make the same article, and think that they succeed"); Playboy Enters. v. Netscape Commc'ns, 354 F.3d 1020, 1035 (9th Cir. 2004) (Berzon, J., concurring) (citing example of department stores that locate clothing from competing manufacturers next to their own house brands). As we explained elsewhere:

The trademark use doctrine has broad application: because of it, newspapers are not liable for using a trademarked term in a headline, even if the use is confusing or misleading. Writers of movies and books are not liable for using trademarked goods in their stories. Makers of telephone directories are not liable for putting all the ads for taxi services together on the same page. In-house marketing surveyors are not liable for asking people what they think of a competitor's brand-name product. Magazines are not liable for selling advertisements that relate to the content of their special issues, even when that content involves trademark owners. Gas stations and restaurants are not liable for locating across the street from an established competitor, trading on the attraction the established company has created or benefiting from the size of the sign the established company has put up. Individuals are not liable for use of a trademark in conversation, even in an inaccurate or misleading way (referring to a Puffs brand facial tissue as a "Kleenex," or a competing cola as a "Coke," for example). Generic drug manufacturers are not liable for placing their drugs near their brandname equivalents on drug store shelves, and the stores are not liable for accepting the placement. They may be making money from their "uses" of the trademark, and the uses may be ones the trademark owner objects to, but they are not trademark uses and therefore are not within the ambit of the statute.

Dogan \& Lemley, Trademarks and Consumer Search Costs, supra note 11, at 809-10.

The assumption that free riding must be rooted out is an increasingly common one in intellectual property law. Indeed, David Franklyn has argued that a focus on free riding, and not any overarching theory of trademark protection, best explains the trademark dilution cases. See David J. Franklyn, Debunking Dilution Doctrine: Toward a Coherent Theory of the Anti-Free-Rider Principle in American Trademark Law, 56 HASTINGS L.J. 117 (2004). One of the authors has elsewhere explained why the focus on free riding is mistaken. Mark A. Lemley, Property, Intellectual Property, and Free Riding, 83 Tex. L. REv. 1031 (2005); Mark A. Lemley, What's Different About Intellectual Property, 83 TEX. L. Rev. 1097 (2005); see also Wendy J. Gordon, On Owning Information: Intellectual Property and the Restitutionary Impulse, 78 VA. L. REV. 149, 167 (1992) ("A culture could not exist if all free riding were prohibited within it."). 
merchandising right even exists and are even more dubious of its existence in the absence of consumer confusion. ${ }^{199}$ Merchandising is likely to receive an even colder reception in the Supreme Court. The Supreme Court's trademark jurisprudence over the past decade has shown a return to core trademark values, with consumer expectations as a central focus and the value of competition paramount. ${ }^{200}$ At the very least, these cases validate the trend toward requiring confusion in merchandising cases, and away from the more generalized right enunciated in Boston Hockey and its progeny. But they may go much further. Beyond reaffirming an approach to trademark law heavily rooted in informational harm and consumer expectations, these opinions manifest a deeprooted concern for the inherent value of competition in product markets. If competitive markets are the ultimate goal, the solution, even in merchandising cases raising risks of sponsorship-based confusion, may lie in something short of an absolute injunction against use of the mark. ${ }^{201}$ This fact makes it all the more surprising that trademark owners, retail businesses, and even government officials simply assume the existence of such a right. ${ }^{202}$

Given the weakness in the trademark owners' claim to ownership of a property right in their trademarks, it is quite surprising that the right of publicity appears increasingly to be based on just such a theory. ${ }^{203}$ Right of publicity plaintiffs don't just want to prevent the use of their names and likenesses in commercial advertising that may falsely suggest endorsement or blur the connection between the name and the person. Rather, they seek to (and increasingly do) control any use of their name or image (or any other aspect of their "personality") ${ }^{204}$ for profit, even where the desire is to depict the plaintiff in an artistic or news format. Thus, the estate of Martin Luther King, Jr.

199. Dogan \& Lemley, Merchandising Right, supra note 11, at 472-78. This doctrinal disagreement is not limited to the United States. In Arsenal Football Club v. Reed, [2003] EWCA (Civ.) 96 [3]-[5] (Eng.), the European Court of Justice (ECJ) established a merchandising right, holding that if both the marks and the goods sold were identical it did not matter whether consumers were confused. The U.K. trial court refused to give effect to this judgment, however, ruling that it was beyond the jurisdiction of the ECJ and that Reed's sale of merchandise featuring the logo of the Arsenal football team did not infringe Arsenal's trademark. The House of Lords ultimately reversed, requiring the establishment of a merchandising right. [2003] ETMR (Civ.) 73.

200. Dogan \& Lemley, Merchandising Right, supra note 11, at 496-506.

201. See generally Bone, supra note 140, at 2182-83 (advocating disclaimer as the exclusive remedy in merchandising cases generally).

202. See, e.g., James Cyphers, Companies Join Police in Pursuing T-Shirt Bootleggers, Wall St. J., Sept. 4, 1991, at B2 (noting law enforcement actions against the sale of $\mathrm{t}$-shirts bearing trademarks and logos).

203. Robert C. Denicola, Institutional Publicity Rights: An Analysis of the Merchandising of Famous Trade Symbols, 62 N.C. L. REV. 603, 627 (1984) (noting the analogy, but concluding that it "cannot be conclusive").

204. Guglielmi v. Spelling-Goldberg Prods., 603 P.2d 454, 457 n.5 (Cal. 1979) (Bird, C.J., concurring) (objecting to the application of the right of publicity to all aspects of one's personality because she could not find "any easily applied definition for this amorphous term"). 
successfully prevented a defendant from selling busts of King, not because people were confused or thought that the estate sponsored them, or because they would somehow dilute King's image, but on a theory that the defendant was trading on goodwill that ought to belong to King's family. ${ }^{205}$ Similarly, the descendants of the Three Stooges prevented sales of an artistic t-shirt featuring their likenesses on the theory that the t-shirt seller profited from the use of those likenesses. ${ }^{206}$ Arnold Schwarzenegger filed suit against the makers of Schwarzenegger bobblehead dolls. ${ }^{207}$ Jessica Simpson sued a company that sold a ring that looked like her wedding ring. ${ }^{208}$ And numerous cases hold that t-shirts, posters, buttons, and other memorabilia violate the right of publicity. ${ }^{209}$ The complaint is not that the defendants engaged in commercial speech because they advertised something - they didn't — but that they are making money using the famous name. ${ }^{210}$ Perhaps broadest in this respect is the Ohio right, which appears to preclude the use for one's own "benefit the name or likeness of another," whether or not the use or benefit is a commercial one. ${ }^{211}$

Even cases that reject merchandising-style right of publicity claims generally do so not because of the problems with a claim of inherent entitlement, but because they see some countervailing value to permitting the use. Thus, in ETW Corp. v. Jireh Publishing, Inc., the court rejected Tiger Woods's claim to own the exclusive right to depict his image in works of art, not because there was no basis for such a right but because the particular painting at issue in that case was art of sufficient quality that the court thought it was protectable expression. ${ }^{212}$ Had the defendant in that case depicted Tiger Woods on a t-shirt, the court might well have reached the opposite

205. Martin Luther King, Jr., Ctr. for Social Change, Inc. v. Am. Heritage Prods., Inc., 296 S.E.2d 697 (Ga. 1982).

206. Comedy III Prods., Inc. v. Gary Saderup, Inc., 21 P.3d 797 (Cal. 2001).

207. John Broder, Schwarzenegger Files Suit Against Bobblehead Maker, N.Y. TimES, May 18, 2004, at A16.

208. Simpson v. Inspired Silver, Inc., No. SACV 05-3 (DOC (ANx) (C.D. Cal. filed Jan. 3, 2005).

209. See, e.g., Factors Etc., Inc. v. Pro Arts, Inc., 579 F.2d 215, 221 (2d Cir. 1978); Winterland Concessions Co. v. Sileo, 528 F. Supp. 1201, 1214 (N.D. Ill. 1981); REstATEMENT (ThiRD) OF UNFAir COMPETITION § $47 \mathrm{cmt}$. b (1995) (“An unauthorized appropriation of another's name or likeness for use on posters, buttons, or other memorabilia is ... ordinarily actionable as an infringement of the right of publicity.").

210. Cf. Hoffman v. Capital Cities/ABC, Inc., 255 F.3d 1180, 1186 (9th Cir. 2001) (finding the use of an image of Dustin Hoffman on a magazine cover to be commercial advertising or promotion because the goal of the use was "to draw attention to the for-profit magazine in which it appears" and therefore help sell copies).

211. Zacchini v. Scripps-Howard Broad. Co., 351 N.E.2d 454, 455 (Ohio 1976), aff'd, 433 U.S. 562 (1977). To be sure, Zacchini appeared to be a particularly compelling case for the plaintiff, whose entire fifteen-second act was shown for free on the nightly news. But the statement of the right of publicity by the Ohio Supreme Court is sweeping indeed, and would appear to encompass any kind of news reporting, commentary, or discussion, even in a private home.

212. 332 F.3d 915, 936-38 (6th Cir. 2003). 
conclusion. ${ }^{213}$ Indeed, the court in ETW referred to the right of publicity as "the inherent right of every human being to control the commercial use of his or her identity." 14 And in Montana v. San Jose Mercury News, Inc., the court rejected a right of publicity claim by football player Joe Montana only because the defendant's use was a reproduction of a newspaper page, and newspapers were entitled to special protection. ${ }^{215}$

Claims of this sort don't work under trademark law. With the exception of a couple of cases, trademark courts tend to base merchandising rights on proof of consumer confusion rather than on some naked right to control any use of a mark. Nor do trademark courts try to draw a distinction between "high art" and commerce. ${ }^{216}$ In Rock and Roll Hall of Fame and Museum, Inc. v. Gentile Productions, for example, the plaintiff protected the unique design of its museum as a trademark and sought to prevent the defendant, a photographer, from selling postcards depicting the Cleveland skyline and prominently featuring the museum. ${ }^{217}$ The court did not try to decide whether the defendant's photographs were sufficiently artistic; instead it found that the plaintiffs had not made "trademark use" of the overall design of the museum to brand particular goods. ${ }^{218}$

The disconnect between the limited merchandising right in trademark law and the broad interpretation given to the right of publicity is striking. One could imagine a right of publicity that extended to t-shirts or note cards in particular cases because a significant segment of the public believes that the celebrity or his estate sold or sponsored the goods. But the right of publicity cases never even ask this question. Rather, courts presume the answer to what would be the central factual question in a trademark inquiry. Doing so comes at a significant price to the public, both in terms of speech and economics. Individuals wanting to express their identification with a particular celebrity, cause, or sports team have to pay a higher price to do so under this expansive reading of the right of

213. See id. at 938; cf. CAL. CIV. CoDE $\S 3344.1(a)(2)$, (3) (2005) (attempting to exempt "single and original work[s] of art" and "work[s] of political or newsworthy value," as well as advertisements for such works, while creating liability for uses of works that are "so directly connected with a product, article of merchandise, good or service as to constitute an act of advertising, selling, or soliciting purchases ... by the deceased personality"). As if that weren't confusing enough, the section just quoted applies only to dead people; an entirely different statute applies to living persons. See CAL. CIV. CodE $§ 3344$ (2005).

214. ETW, 332 F.3d at 928.

215. 40 Cal. Rptr. 2d 639, 643 (Ct. App. 1995); see also Gionfreddo v. Major League Baseball, 114 Cal. Rptr. 2d 307 (Ct. App. 2001).

216. Cf. Greggs, supra note 180, at 1302-14 (explaining how the right of publicity cases attempt to draw such a distinction).

217. 134 F.3d 749, 750-51 (6th Cir. 1998).

218. Id. at 754-55. Interestingly, the court expressly drew an analogy to the attempt to register images of celebrities as trademarks, distinguishing one particular image serving a brand-identifying function from the overall look of the celebrity himself. Id. (citing Estate of Presley v. Russen, 513 F. Supp. 1339, 1363-64 (D.N.J. 1981) (concluding that use of one image of Elvis Presley as a mark did not justify trademark rights over all pictures of Elvis)). 
publicity than they would under a system that allowed uses that did not imply source-identification or endorsement. ${ }^{219}$ Companies that provide useful goods and services, like fantasy sports leagues, face suits claiming that they have no right to use data that relates to an individual. ${ }^{220}$ Given the weakness of the merchandising theory in trademark cases, it seems unwise to base so much of the right of publicity on an expanded version of a merchandising right.

\section{B. Do We Need a Separate Right of Publicity at All?}

If we are right that trademark law is the closest analogy to the right of publicity, it is reasonable to ask how far that analogy extends. Might we be better off without a right of publicity altogether, relying on the Lanham Act itself to protect the trademark-like interests we have identified? Certainly the Lanham Act has provided relief in a number of cases involving publicity interests. $^{221}$ Some commentators have suggested abolishing the right of publicity outright. ${ }^{222}$ We think there are two reasons to retain the doctrine in independent form, however.

\section{Non-trademark theories}

First, not all explanations for the right of publicity fit neatly within the trademark framework. We discussed two such explanations in Part I-the circular justification that "I own it because it's mine" and the historical privacyprotecting justification for the right. The former maps most neatly to the merchandising right, though some (notably McCarthy) have argued that control over one's name is more properly thought of as a natural right than a trademark

219. These economic and speech costs come into play not only with t-shirts and other plainly expressive merchandise, but also with pencil sharpeners and other trinkets. While the gravity of the speech interests may well differ somewhat from one product to the next, courts should not get into the business of making such content-based distinctions absent some compelling reason to recognize a merchandising-based publicity right in the first place.

220. See, e.g., Neil deMause, Fantasy Firefight, Baseball Prospectus, Feb. 16, 2005, http://www.baseballprospectus.com/article.php?articleid=3763.

221. See, e.g., Rostropovich v. Koch Int'l Corp., 34 U.S.P.Q.2d (BNA) 1609 (S.D.N.Y. 1995) (allowing cellist Mstislav Rostropovich to prevent the sale of a CD with copies of his work); Jackson v. MPI Home Video, 694 F. Supp. 483 (N.D. Ill. 1988) (holding that Jesse Jackson could prevent the sale of a video of his speech and bearing his likeness because people might believe he had authorized the video); Allen v. Nat'l Video, Inc., 610 F. Supp. 612 (S.D.N.Y. 1985) (holding that Woody Allen could stop the use of look-alikes who might confuse viewers).

222. See, e.g., Lee Goldman, Elvis Is Alive, but He Shouldn't Be: The Right of Publicity Revisited, 1992 BYU L. REV. 597, 625-28; cf. Usha Rodrigues, Note, Race to the Stars: A Federalism Argument for Leaving the Right of Publicity in the Hands of the States, 87 VA. L. REV. 1201, 1209 (2001) (arguing against a federal right of publicity in part because the Lanham Act already takes care of legitimate publicity interests). 
is. ${ }^{223}$ But as we explained in Part I.B, there is no such natural right in a personal name. We permit countless uses of another's name for profit, in all sorts of contexts - newspapers, comedy routines, movies, and books, to name but a few. The natural rights theory of the right of publicity fits imperfectly with trademark law, but it fits imperfectly with the right of publicity as well. It is not, in our view, a defensible justification for a right of publicity, so the imperfect fit doesn't present a problem for our theory.

Privacy-based justifications for the right of publicity, by contrast, are legitimate and depart from the trademark rationale. They have the advantage of history - the right of publicity itself began as one of four privacy torts elucidated in the famous Warren-Brandeis article. ${ }^{224}$ To the extent that the right of publicity is in fact justified on a privacy theory, ${ }^{225}$ that theory properly coexists with reputation-related theories of the sort we discuss in this Article. We think, however, that inclusion of privacy-based publicity requires only a minor modification to the broad sweep of our reputation-based approach. Privacy is implicated only when a plaintiff seeks to avoid commercial exposure and is unwillingly subjected to it. ${ }^{226}$ It therefore coexists uneasily, if at all, with celebrity, since most of the celebrities enforcing the right of publicity affirmatively want commercial use made of their name- they just want to get

223. 1 MCCARTHY, supra note $4, \S 2: 8$ (arguing that the Lanham Act can't protect right of publicity interests because he believes the right of publicity doesn't require any element of falsity). Trademark law does show some extra solicitude toward personal names, particularly in older decisions. See, e.g., Brown Chem. Co. v. Meyer, 139 U.S. 540, 544 (1891) ("A man's name is his own proper[t]y, and he has the same right to its use and enjoyment as he has to that of any other species of property."); Abdul-Jabbar v. Gen. Motors Corp., 85 F.3d 407, 415-16 (9th Cir. 1996) (holding that a personal name cannot be abandoned through non-use); Stix, Baer \& Fuller Dry Goods Co. v. Am. Piano Co., 211 F. 271, 274 (8th Cir. 1913); Burgess v. Burgess, 43 Eng. Rep. 351, 354 (1853). But trademark courts have not hesitated to enjoin the use of one's own name for commercial purposes where that use might in fact confuse consumers. See, e.g., Thaddeus Davids Co. v. Davids Mfg. Co., 233 U.S. 461, 472 (1914); E. \& J. Gallo Winery v. Gallo Cattle Co., 967 F.2d 1280 (9th Cir. 1992); Basile, S.p.A. v. Basile, 899 F.2d 35, 39-40 (D.C. Cir. 1990); Taylor Wine Co. v. Bully Hill Vineyards, Inc., 569 F.2d 731 (2d Cir. 1978); Hat Corp. of Am. v. D.L. Davis Corp., 4 F. Supp. 613, 623 (D. Conn. 1933). And efforts to take advantage of any special solicitude toward personal names by changing one's name have not fared well. See Univ. of Oxford v. Seagle, No. D2001-0746 (WIPO Aug. 14, 2001) (ordering transfer of domain name university-of-oxford.com despite claims of registrant, who had legally changed his personal name to Oxford University).

224. Warren \& Brandeis, supra note 16.

225. Some courts have held that this is the only permissible justification for a right of publicity. See, e.g., Stephano v. News Group Publ'ns, Inc., 474 N.E.2d 580, 584 (N.Y. 1984).

226. Some noncelebrity cases have a different flavor-an individual is happy to have his or her image used for commercial purposes, but wants more money. Thus, Russell Christoff won \$15.6 million from Taster's Choice Coffee even though he had been paid to model for them, on the theory that posing in a model shoot did not give the defendants the right to use the pictures they had taken. See Taster's Choice Model Wins \$15.6M Judgment From Nestle, IP L. BuLl., Feb. 2, 2005, http://www.iplawbulletin.com/chi-bin/absolutenm/ anmviewer.asp? $\mathrm{a}=2966 \& \mathrm{z}=18$. 
paid for it. ${ }^{227}$ A privacy rationale is also inconsistent with the idea that an individual's right of publicity can be assigned like any other form of property. While there are a few cases in which noncelebrities assert the right of publicity because they really do want to be left alone, ${ }^{228}$ they are neither the typical right of publicity cases $^{229}$ nor the cases likely to create problems for the doctrine. ${ }^{230}$

\section{Imperfect fit of trademark protection}

A second reason to maintain an independent right of publicity is that some of the requirements of trademark law don't translate well to the context of the right of publicity. ${ }^{231}$ First, trademark law generally requires that the trademark

227. One exception may be Midler v. Ford Motor Co., 849 F.2d 460, 462-63 (9th Cir. 1988), where the plaintiff refused to do commercial advertising at all. See also Waits v. Frito-Lay, Inc., 978 F.2d 1093 (9th Cir. 1992) (allowing false endorsement claim by Tom Waits, who rejected commercial endorsement opportunities as a matter of principle). Other exceptions involve claims that are really variants on the privacy tort of public disclosure of private facts, such as the European paparazzi cases, see Von Hannover v. Germany, 40 Eur. Ct. H.R. 1 (2004); Campbell v. MGN Ltd., [2004] 2 A.C. 457 (H.L.), or cases addressing videos involving the plaintiff's nudity or sexual conduct. The problem with treating these latter claims under the right of publicity is that, at least under the Restatement of Unfair Competition, liability depends on whether the plaintiff's image was used in advertising to sell products not featuring the plaintiff, something not true in these cases. See Lane v. MRA Holdings, 242 F. Supp. 2d 1205, 1213-15 (M.D. Fla. 2002) (rejecting liability where plaintiff's image was used to advertise the video in which she was featured). Contra Bosley v. Wildwett.com, 310 F. Supp. 2d 914, 922-23 (N.D. Ohio 2004) (finding liability where plaintiff's image was used to advertise a video, regardless of the fact that she was featured).

228. See Dora v. Frontline Video, Inc., 18 Cal. Rptr. 2d 790, 792 n.2 (Ct. App. 1993) (extending protection to noncelebrities, but noting a split among courts as to whether noncelebrities are even entitled to assert a right of publicity); RESTATEMENT (THIRD) OF UNFAIR COMPETITION $§ 46 \mathrm{cmt}$. d (1995).

229. 1 MCCARTHY, supra note $4, \S 4: 14$ ("[M] ost reported right of publicity cases have involved plaintiffs who were 'celebrities' ....").

230. While most privacy claims involve noncelebrities, there are two limited circumstances in which celebrities might have a legitimate privacy-related cause of action. First, the fact that celebrities have sought the spotlight does not mean that they have waived all expectations of privacy; they may still have a claim based on the unauthorized disclosure of truly private matters, when the intrusiveness of the disclosure outweighs any potential newsworthiness of the content. Such a claim may fall within the rubric of public disclosure of private facts, or the tort of intrusion upon a party's solitude or into her private affairs. E.g., Michaels v. Internet Entm't Group, Inc., 5 F. Supp. 2d 823, 828 (C.D. Cal. 1998) (granting preliminary injunction against the distribution of video showing celebrity couple engaged in sexual intercourse). Second, particularly given the ease of manipulation of digital photographs, celebrity images may sometimes be modified and presented in a false and harmful light. In these circumstances, the celebrity could bring a claim based on the tort of false light privacy. See Clay Calvert \& Justin Brown, Video Voyeurism, Privacy, and the Internet: Exposing Peeping Toms in Cyberspace, 18 CARDOZO ARTS \& ENT. L.J. 469, 565-66 (2000) (noting availability of false light privacy claims in cases involving alteration or manipulation of celebrity images in ways that cause personal distress).

231. Cf. Konsky, supra note 171 , at $362-63$ (arguing that adoption of a publicity dilution statute would be preferable to simply incorporating personal names into the 
owner use the mark in commerce in the United States, on or in connection with the sale of goods or services. ${ }^{232}$ While some courts have extended the Lanham Act to cover "signature" uses of celebrity identities in the false endorsement context, ${ }^{233}$ others suggest that those who use a name as a brand may not be entitled to protect other aspects of their personality, such as their image or voice, under trademark law, ${ }^{234}$ at least without proof that each particular aspect had acquired secondary meaning. ${ }^{235}$ These requirements make little sense in the context of personal likeness. There should be no requirement of use in commerce or secondary meaning under the right of publicity; ${ }^{236}$ noncelebrities, foreign celebrities, and celebrities who refuse to trade on their name ought equally to be able to prevent confusing or diluting uses of their names and likenesses.

A second problem with eliminating the right of publicity altogether lies in the Supreme Court's recent decision in Dastar Corp. v. Twentieth Century Fox Film Corp. ${ }^{237}$ There, the Court properly rejected efforts by the former owner of an expired copyright in a television series to use trademark law to prevent the sale of a copy of the series by others on the theory that they were passing off the plaintiff's work as their own. The Court's rationale, however, suggested that trademark law could never provide a cause of action against "the use of

trademark dilution statute because "[a]s it stands, trademark law is not equipped to subsume the right of publicity").

232. 15 U.S.C. § 1051(a) (2006) (requiring "use in commerce"); § 1127 (defining "use in commerce"). For a discussion of the history and importance of the trademark use doctrine, see Margreth Barrett, Internet Trademark Suits and the Demise of "Trademark Use," 39 U.C. DAVIS L. REV. (forthcoming February 2006).

233. White v. Samsung Elecs. Am., Inc., 971 F.2d 1395, 1399-1401 (9th Cir. 1992).

234. See, e.g., Condit v. Star Editorial, 259 F. Supp. 2d 1046, 1054 (E.D. Cal. 2003) (rejecting a trademark claim based on identity where the plaintiff had never commercialized her identity); Estate of Presley v. Russen, 513 F. Supp. 1339, 1363-64 (D.N.J. 1981) (rejecting claim that estate of Elvis Presley was entitled to trademark all uses of his image).

235. See, e.g., Flynn v. AK Peters, Ltd., 377 F.3d 13, 22 (1st Cir. 2004) (finding that author's name lacked sufficient secondary meaning to justify passing-off claim); ETW Corp. v. Jireh Publ'g, Inc., 332 F.3d 915, 922 (6th Cir. 2003) ("[A]s a general rule, a person's image or likeness cannot function as a trademark."); Pirone v. MacMillan, Inc., 894 F.2d 579, 583 (2d Cir. 1990) ("[A] photograph of a human being . . . is not inherently 'distinctive' in the trademark sense . . . ."); Allen v. Men's World Outlet, Inc., 679 F. Supp. 360, 362 (S.D.N.Y. 1988) ("If Allen's claim is that his likeness rather than his face is a trademark, it would not appear to be dilutable....").

236. See Eastwood v. Superior Court, 198 Cal. Rptr. 342, 348 (Ct. App. 1983) (holding that secondary meaning was not required). But cf. Lugosi v. Universal Pictures, 603 P.2d 425, 428, 430 (Cal. 1979) (requiring proof of secondary meaning to protect a right of publicity after death); Brees Co., Inc. v. Brees Co., Inc., No. FA0506000493869 (NAF July 28,2005 ) (concluding football star could not win cybersquatting complaint against defendant who registered his name before he became famous). McCarthy calls the Lugosi decision "an unfortunate mish-mash of terminology." 4 MCCARTHY, TRADEMARKS, supra note 4 , § 28:8 n.5.

237. 539 U.S. 23 (2003). 
otherwise unprotected works and inventions without attribution." ${ }^{238}$ Rather, a trademark cause of action for a copyrighted work was limited to misleading the public as to "the producer of the tangible goods that are offered for sale, and [does] not [extend] to the author of any idea, concept, or communication embodied in those goods." 239 Whatever the merits of Dastar as a matter of trademark law, ${ }^{240}$ the right of publicity should chart a different course. No one should be permitted to use an actor's or author's name to falsely suggest connection or endorsement merely because the copyright in the underlying work in which the name appeared has expired. Copyright lasts for a sufficiently long time that copyright protection will rarely expire before the right of publicity does, but should that occur, the right of publicity ought to survive. ${ }^{241}$

A final reason for the continued need for the right of publicity lies in the rare dilution-type right of publicity case. Unlike the Lanham Act's general unfair competition provision, ${ }^{242}$ the federal dilution statute applies only to "famous" and distinctive trademarks. ${ }^{243}$ The categorical language of the FTDA makes it unlikely that the statute would apply to the blurring or tarnishment of a celebrity's identity, particularly in the Second Circuit, which excludes personal names from dilution protection altogether. ${ }^{244}$ The right of publicity should play

238. Id. at 36 .

239. Id. at 37.

240. For trenchant criticism of the decision, see, for example, Jane C. Ginsburg, The Author's Name as a Trademark: A Perverse Perspective on the Moral Right of 'Paternity'? (Columbia L. Sch. Pub. L. \& Legal Theory Working Paper Group, Paper No. 05-91, 2005), http://ssrn.com/abstract=724343 (last visited Jan. 31, 2006); Greg Lastowka, The Trademark Function of Authorship, 85 B.U. L. REV. 1171 (2005). But see Jonathan Band \& Matt Schruers, Dastar, Attribution, and Plagiarism, 33 AIPLA Q.J. 1, 2 (2005) (defending the decision on both legal and policy grounds).

241. The preemption of the right of publicity by copyright law is a complex field. Most courts agree that copyright law does not wholly preempt the state right of publicity. See, e.g., Toney v. L'Oreal USA, Inc., 406 F.3d 905, 910-11 (7th Cir. 2005). But the right of publicity cannot interfere with the ability of copyright owners to distribute their movies merely because the actor is portrayed in those works. See Fleet v. CBS, Inc., 58 Cal. Rptr. 2d 645 (Ct. App. 1996). One court has extended that reasoning to conclude that baseball players could not assert right of publicity claims in their game performances or their images in uniform, because those were embodied in copyrighted telecasts. Baltimore Orioles, Inc. v. Major League Baseball Players Ass'n, 805 F.2d 663, 674 (7th Cir. 1986).

The extent of copyright preemption may depend on whether the right of publicity claimed is a traditional one limited to commercial advertising and false endorsement, or whether it extends to any use of an image. The latter sort of claim seems equivalent to a copyright owner's exclusive right to copy or display a work, and therefore more likely to be preempted. See Shelley Ross Saxer, Note, Baltimore Orioles, Inc. v. Major League Baseball Players Association: The Right of Publicity in Game Performances and Federal Copyright Preemption, 36 UCLA L. REV. 861, 881-82 (1989).

242. 15 U.S.C. $\$ 1125(a)$ (2006).

243. $§ 1125(\mathrm{c})$.

244. TCPIP Holding Co. v. Haar Commc'ns, Inc., 244 F.3d 88 (2d Cir. 2001) (requiring inherent distinctiveness for protection against dilution). Because personal names are treated as descriptive, they will not meet this standard regardless of their fame. 
a continuing role in those cases.

While these differences justify the existence of a right of publicity independent of trademark law, and with somewhat divergent rules, they do not undermine the power of the trademark analogy or rise to the level of an independent justification for the right of publicity. Rather, they are better understood as adaptations designed to achieve trademark-related goals like preventing confusing false endorsements in the somewhat different context of personal names.

\section{IMPLICATIONS OF THE TRADEMARK APPROACH}

If courts were to turn to trademark law to understand the justifications for and limits on the right of publicity, how would that affect the law? We see two significant effects, both in our view beneficial: the right would have a less expansive scope than some recent decisions have given it, and courts would not hesitate to apply the First Amendment to limit the right of publicity.

\section{A. Substantive Implications for Right of Publicity Doctrine}

First, the rationales we offered in Part III for the right of publicity are not coextensive with the broad scope some states have given the doctrine. While some states, like Florida, properly limit the doctrine to use of a name or likeness in commercial advertising and promotion, rather than extending it to any use made for profit ${ }^{245}$ (and even then permit accurate advertising of the contents or nature of a product $\left.{ }^{246}\right)$, other states have let their right of publicity drift well beyond logical doctrinal moorings. California is the most notable example. The California right of publicity has turned from a right to prevent the use of a name to suggest endorsement without consent into a right to control almost any use of any reference to a person if the user makes money as a result. ${ }^{247}$ Further, California law extends this right for decades after a person's

245. See, e.g., Valentine v. CBS, Inc., 698 F.2d 430, 433 (11th Cir. 1983) (stating that Florida right of publicity law requires proof that the plaintiff's name or likeness was used to promote a product or service); Lane v. MRA Holdings, 242 F. Supp. 2d 1205, 1215 (M.D. Fla. 2002) ("[T]he publication of Girls Gone Wild is not actionable simply because it is sold for a profit.”); Tyne v. Time Warner Entm't Co., 901 So. 2d 802 (Fla. 2005).

246. Lane, 242 F. Supp. 2d at 1213 (allowing producer of video to use image of plaintiff in promoting a video that included footage of plaintiff).

247. The California Civil Code provides that anyone who uses another's "name, voice, signature, photograph, or likeness, in any manner, on or in products, merchandise, or goods, or for purposes of advertising or selling" must forfeit his or her profits and shall also be liable for damages and attorneys fees. CAL. CIV. CODE § 3344(a) (2005) (emphasis added). The statute exempts use "in connection with any news, public affairs, or sports broadcast or account, or any political campaign," $§ 3344(d)$, but by its terms holds liable anyone who depicts another in a work of art, a movie or television show, a play, a song, or a book. Movies such as "Forrest Gump" and "Contact," which depict fictional characters interacting with real historical figures, would therefore violate California's right of publicity. So too 
death, albeit with further restrictions than it does during his life. ${ }^{248}$ California courts have occasionally recognized that this expansive right needs some limits, but they have generally turned to copyright analogies in a fruitless search for limiting principles. ${ }^{249}$ As we explained in Part II, however, copyright is not the right analogy. Thinking about the right of publicity by comparing the plaintiff's claim to the goals served by trademark law will help courts and legislators to find coherence in the doctrine and to avoid some of the expansive readings given that doctrine by courts that acted without a clear sense of what purpose the law was designed to serve. ${ }^{250}$

The trademark analogy may have other doctrinal implications as well. For example, courts in trademark cases apply a doctrine known as "trademark use," which limits infringement claims to those defendants who have used a mark in connection with the sale or advertising of a good or service. ${ }^{251}$ The trademark use requirement serves a gatekeeper function, limiting the reach of trademark law without requiring a factual inquiry into consumer confusion. The rationale for the doctrine stems from the practical reality that it would be both unwise and impossible to permit trademark owners to control every use of their marks. People and businesses use trademarks every day, in conversation, in news reporting, in songs, and in books. Trademark law has never given trademark owners exclusive control over every use of their marks. Rather, the law is designed to prevent consumer confusion by those who brand their own goods or services with a mark sufficiently similar to the plaintiff's mark such that consumers may be deceived into believing there is some connection between the two. Individuals and companies may make reference to, or use of, a trademark without fear of liability unless they are making a trademark use.

The trademark use doctrine, albeit in a somewhat modified form, may

would "Bowling for Columbine" or any other movie in which a documentary filmmaker depicts a person against her will.

248. See CAL. Civ. Code $§ 3344.1$ (2005). Unlike section 3344, which applies to living people, this section exempts any "play, book, magazine, newspaper, musical composition, audiovisual work, radio or television program, single and original work of art, work of political or newsworthy value, or an advertisement or commercial announcement for any of these works . ...” $\$ 3344.1(a)(2)$. Even this broader list leaves an artist liable if she makes even one reprint of her work. See Comedy III Prods., Inc. v. Gary Saderup, Inc., 21 P.3d 797, 810 (Cal. 2001).

249. E.g., Saderup, 21 P.3d at 808-10.

250. See Konsky, supra note 171, at 347-48 (proposing to limit a right of publicity she considers "too unwieldy and overbroad" by requiring proof of the same elements required in a trademark dilution claim).

251. See, e.g., 1-800 Contacts, Inc. v. WhenU.Com, Inc., 414 F.3d 400, 408 (2d Cir. 2005) (finding no infringement when defendant “ $\mathrm{d}$ [id] not 'use' [plaintiff's] trademark in the manner ordinarily at issue in an infringement claim: it [did] not 'place' [plaintiff's] trademarks on any goods or services in order to pass them off as emanating from or authorized by" the plaintiff); Bosley Med. Inst., Inc. v. Kremer, 403 F.3d 672, 676-80 (9th Cir. 2005). For an extensive discussion of the trademark use doctrine, see Dogan \& Lemley, Trademarks and Consumer Search Costs, supra note 11, at 805-11. 
provide an important tool for checking the right of publicity. Because most publicity cases will involve associational uses rather than source-indicating uses, the type of connection between product and celebrity identity differs somewhat from the typical connection between product and trademark in Lanham Act infringement suits. Nonetheless, we believe that the right of publicity, properly understood, should require a use of celebrity identity as a tool for marketing goods and services, not merely an attempt to refer to a celebrity. ${ }^{252}$

Resort to trademark doctrines should also affect the alienability of the publicity right. As currently conceived, the right of publicity is freely assignable. ${ }^{253}$ McCarthy justifies this result by reminding readers that he considers the right of publicity

an inherent property right ... not analogous to a trademark in this respect. A trademark . . . is merely a symbol of the good will value of an ongoing business. The right of publicity is not so much a symbol of something as it is legal recognition of proprietary value of the persona of every human being. ${ }^{254}$

We have explained above why we think the "inherent property" idea is wrong, and indeed in this case self-contradictory: if we must recognize a right of publicity because someone's persona is inherently his or her own, it makes little sense to treat it as property that can be sold freely. Does it follow from our trademark-based view that the right of publicity cannot be assigned?

With some significant caveats, we think that it does. ${ }^{255}$ A trademarkrelated justification for the right of publicity focuses attention on the use of a personal name to falsely suggest sponsorship or to draw some other mental connection in the minds of an audience between the celebrity and a commercial product. Individuals should have the right to prevent such uses, and the corresponding right to authorize them in exchange for money by choosing to endorse certain products. ${ }^{256}$ But they do not need a right to assign their name in

252. Limiting the right of publicity in this way will admittedly allow some third-party uses that may have a negative impact on celebrity image. Certain celebrities, for example, might disdain the use of their images on t-shirts and other merchandise and might view the sale of such items as a cheapening of their carefully constructed personas. More commonly, however, the celebrity's primary objective is not so much to prevent all merchandising uses, but to exert control over such uses in order to maximize her profit from them. In our view, the economic and speech-related costs of such celebrity control outweigh the interests of individual celebrities in the rare case in which merchandising uses cause identifiable harm.

253. 2 MCCARTHY, supra note 4, $\S 10: 10-14$; cf. Haelan Labs., Inc. v. Topps Chewing Gum, Inc., 202 F.2d 866, 868 (2d Cir. 1953) (permitting the grant of an exclusive license to a publicity right).

254. 2 MCCARTHY, supra note $4, \S 10: 12$.

255. Cf. Westfall \& Landau, supra note 52, at 122 (arguing that some commercial transactions over the right of publicity make sense, but that it should not be inheritable or treated as property more generally in marital property and bankruptcy contexts).

256. Melville Nimmer argued half a century ago that "[t]he pecuniary worth of publicity values will be greatly diminished if not totally destroyed if these values cannot be effectively sold." Melville B. Nimmer, The Right of Publicity, 19 LAW \& CONTEMP. ProBS. 
gross in order to make money from endorsements. They need only the right to license others to use their name for certain products. Trademark owners have a similar right; they need only make sure that they supervise the circumstances in which their name is being used. ${ }^{257}$ The same thing makes sense in the context of the right of publicity. Individuals should be entitled to license others the right to use their name, but if they relinquish all control over that name by selling it to another, the use of their name is more likely to confuse than to inform. ${ }^{258} \mathrm{We}$ think outright assignments, as opposed to licenses of a publicity right, should be forbidden, just as they are in trademark law. ${ }^{259}$

At the same time, not all trademark doctrines will translate readily into the right of publicity context. The policies underlying trademark law's fair use doctrine, for example, do not have the same persuasive force in the context of celebrity identity. While competitors have an obvious need to use well-known trademarks to compare the merits of competing products, they do not have the same compelling need to use the name or likeness of celebrities with which those products have become identified. ${ }^{260}$ Fair use and comparative advertising defenses are therefore less likely to succeed in right of publicity cases.

203, 212 (1954). But in the context of his discussion, it is clear that the right need not actually be sold, only licensed, for a celebrity to derive economic value from it.

257. See, e.g., Stanfield v. Osborne Indus., Inc., 52 F.3d 867, 871 (10th Cir. 1995); 2 MCCARTHY, supra note $4, \S 18: 42$ (discussing the requirement that trademark owners supervise licensing). For debate on whether this is a good rule in the trademark context, compare Stephen L. Carter, The Trouble with Trademark, 99 YALE L.J. 759, 786 (1990), and Lemley, Modern Lanham Act, supra note 136, at 1709-10 (defending the rule), with Irene Calboli, Trademark Assignment "with Goodwill": A Concept Whose Time Has Gone, 57 FlA. L. REV. 771 (2005), and Allison Sell McDade, Note, Trading in Trademarks-Why the Anti-Assignment in Gross Doctrine Should Be Abolished When Trademarks Are Used as Collateral, 77 TEX. L. REV. 465 (1998) (proposing elimination of the rule).

258. This means that it will usually be the celebrity, not a licensee, who has standing to bring suit to enforce the right of publicity. $C f$. Interplanet Prods. Ltd. v. K Myers, No. FA 0504000449882 (Nat'l Arbitration Forum June 28, 2005) (refusing to transfer domain name elizabethtaylor.com to plaintiff, a trademark licensee of Elizabeth Taylor, because she and not the licensee controlled the residual rights to her name). We think this is as it should be.

259. Trademark owners can assign their rights if they do so as part of a sale of the goodwill of the company. See, e.g., In re Roman Cleanser Co., 802 F.2d 207, 208 (6th Cir. 1986); Money Store v. Harriscorp Fin., Inc., 689 F.2d 666, 676 (7th Cir. 1982). But in the right of publicity context, precisely because the right is personal to the owner, it makes little sense to speak of the sale of the individual's celebrity to another.

260. Such uses may well establish a connection in consumers' minds between the celebrity and the competing product even if the competitor includes a disclaimer. Experience in trademark cases has suggested that disclaimers are generally ineffective at dispelling confusion as to association. See, e.g., Charles of the Ritz Group Ltd. v. Quality King Distribs., Inc., 832 F.2d 1317, 1324 (2d Cir. 1987) (noting a "growing body of academic literature" concluding "that disclaimers, especially those... which employ brief negator words such as 'no' or 'not,' are generally ineffective"); Mitchell E. Radin, Disclaimers as a Remedy for Trademark Infringement: Inadequacies and Alternatives, 76 TRADEMARK REP. 59 (1986). 


\section{B. The Right of Publicity and the First Amendment}

Relying on the trademark rather than the copyright analogy will also ensure a continued role for the First Amendment in the right of publicity. Some courts and commentators have assumed that limiting the publicity right to commercial speech solves the First Amendment problem, since commercial speech is not entitled to full First Amendment protection. ${ }^{261}$ But as Judge Kozinski noted in his White v. Samsung dissent, "less protected means protected nonetheless."262 Commercial uses of someone's likeness are speech subject to First Amendment protection, and in many cases the speech will have clear political or social content that would be stifled by application of the right of publicity. ${ }^{263}$ Indeed, White itself is an example. White involved a humorous parody of the set of the game show Wheel of Fortune in 2012 A.D., in which host Vanna White had been replaced by a robot in a blond wig. It is hard to understand how the injunction against that parody could survive ordinary First Amendment scrutiny, for example. ${ }^{264}$

Further, the right of publicity doesn't arise only in the context of commercial speech. The diminished protection afforded commercial speech is generally limited to commercial advertising; certainly the fact that an item is sold commercially doesn't make it commercial speech, or else most newspapers, magazines, and books would fall into this less protected category. The courts, though, have found right of publicity violations in some noncommercial uses of a plaintiff's image. For instance, while sculpturessuch as busts of Martin Luther King, Jr.-are generally seen as core protected speech, the King estate won a right of publicity case against the distributors of such sculptures. ${ }^{265}$ Paintings, photographs, and even inscriptions on t-shirts are generally seen as core protected speech, ${ }^{266}$ but they too may infringe the right

261. See 1 McCarthy, supra note 4, at $\S 3: 46$ (listing and discussing cases). Portions of this paragraph and the next one are adapted from Lemley \& Volokh, supra note 180, at $225-26$.

262. White v. Samsung Elecs. Am., Inc., 989 F.2d 1512, 1519 (9th Cir. 1993) (Kozinski, J., dissenting from denial of rehearing en banc). Further, Eugene Volokh notes that in California at least truthful commercial speech is now entitled to full constitutional protection. Volokh, supra note 76, at 925-27.

263. See, e.g., Michael A. Carrier, Cabining Intellectual Property Through a Property Paradigm, 54 DUKE L.J. 1, 142 (2004) ("[T]he right of publicity thus threatens to suppress expression and to give celebrities the power to censor alternative versions of their images ....").

264. See White, 989 F.2d at 1519 (Kozinski, J., dissenting from denial of rehearing en banc) (" $[\mathrm{N}]$ ot allowing any means of reminding people of someone? That's a speech restriction unparalleled in First Amendment law.").

265. See Martin Luther King, Jr., Ctr. for Soc. Change, Inc. v. Am. Heritage Prods., Inc., 296 S.E.2d 697 (Ga. 1982).

266. See Ayres v. City of Chicago, 125 F.3d 1010, 1014 (7th Cir. 1997) ("[T]here is no question that the t-shirts are a medium of expression prima facie protected by the free-speech clause of the First Amendment, and they do not lose their protection by being sold rather than given away."); Gaudiya Vaishnava Soc'y v. City \& County of San Francisco, 952 F.2d 
of publicity. ${ }^{267}$

The speech-restrictive implications of a right to prevent someone else from talking about you should be obvious. ${ }^{268}$ They parallel the concerns with giving a company the right to prevent someone else from speaking about it. Trademark cases resolve those concerns by limiting liability to circumstances in which the defendant engages in commercial speech that is false or misleading. ${ }^{269}$ Where a use is expressive and not merely commercial speech, trademark courts generally apply the First Amendment. ${ }^{270}$ First Amendment cases involving the right of publicity have traditionally done the same thing, limiting the application of the doctrine to commercial speech and focusing attention on false endorsement. Where the right of publicity overstepped those bounds, courts have not hesitated to use constitutional law to rein it in. ${ }^{271}$

1059, 1064 (9th Cir. 1991) (holding that merchandise which exhibits protected expression is protected speech); $c f$. City of Lakewood v. Plain Dealer Publ'g Co., 486 U.S. 750,756 n.5 \& 768 (1988) (holding that the act of selling protected works is itself protected speech).

267. See Wendt v. Host Int'l, Inc., 125 F.3d 806, 811-12 (9th Cir. 1997) (holding that licensees of "Cheers" television show could violate the right of publicity by using robots that looked like characters from the show in "Cheers" theme bars); Factors Etc., Inc. v. Pro Arts, Inc., 579 F.2d 215, 222 (2d Cir. 1978) (holding that a poster depicting Elvis Presley infringed the Presley estate's right of publicity); Winterland Concessions Co. v. Sileo, 528 F. Supp. 1201, 1214 (N.D. Ill. 1981) (holding that t-shirts depicting band logos violated the right of publicity), aff'd on other grounds, 735 F.2d 257 (7th Cir. 1984); RESTATEMENT (THIRD) OF UNFAIR COMPETITION $§ 47 \mathrm{cmt}$. b (1995) ("An unauthorized appropriation of another's name or likeness for use on posters, buttons, or other memorabilia is . . ordinarily actionable as an infringement of the right of publicity."). In our view, the sort of "decor speech" at issue in Wendt doesn't fit within the traditional definition of commercial speech, because it doesn't propose a commercial transaction.

268. See Shubha Ghosh, On Bobbling Heads, Paparazzi, and Justice Hugo Black, 45 SANTA Clara L. REV. 617 (2005); Volokh, supra note 76, at 908-12; David S. Welkowitz \& Tyler T. Ochoa, The Terminator as Eraser: How Arnold Schwarzenegger Used the Right of Publicity To Terminate Non-Defamatory Political Speech, 45 SANTA Clara L. ReV. 651 (2005).

269. See, e.g., Lemley \& Volokh, supra note 180, at 221-22; cf. Friedman v. Rogers, 440 U.S. 1, 15 (1979) (holding that a state's interest in protecting the public from confusion will justify a restriction on misleading speech). Lemley and Volokh go on to note, however, that the rationale of preventing consumer confusion provides little constitutional support for dilution doctrine, which is nominally not targeted at conduct that misleads consumers. Lemley \& Volokh, supra note 180, at 221 n.325. One benefit of understanding dilution law as we have explained it elsewhere - as directed at reducing consumer search costs, see Dogan \& Lemley, Merchandising Right, supra note 11, at 493-is that our approach may reduce the tension between dilution law and the First Amendment.

270. See, e.g., Rogers v. Grimaldi, 875 F.2d 994, 999-1002 (2d Cir. 1989) (permitting a movie about ballroom dancing to use the title "Fred and Ginger" where the title was artistically relevant, even though the movie was not in fact about Ginger Rogers).

271. See, e.g., Cardtoons, L.C. v. Major League Baseball Players Ass'n, 95 F.3d 959 (10th Cir. 1996) (holding First Amendment interest in selling baseball card parodies outweighed right of publicity); Matthews v. Wozencraft, 15 F.3d 432 (5th Cir. 1994) (holding the right of publicity could not prevent a fictionalized biographical narrative about plaintiff); Stephen R. Barnett, First Amendment Limits on the Right of Publicity, 30 TORT \& INS. L.J. 635 (1995); Dougherty, supra note 65; Ellis, supra note 127; Bruce P. Keller \& 
Courts may not always get it right in trademark First Amendment cases, but they are at least engaging in the right analysis.

Copyright law, by contrast, has long gotten a free ride from the First Amendment, despite considerable scholarly commentary explaining the dangers copyright poses to free speech, ${ }^{272}$ on the theory that such limiting doctrines as fair use and the idea-expression dichotomy prevent the conflict

Rebecca Tushnet, Even More Parodic than the Real Thing: Parody Lawsuits Revisited, 94 TRADEMARK REP. 979, 1009 (2004) ("It is not surprising, then, that courts have incorporated trademark-like First Amendment and fair use defenses into their right of publicity analyses ...."); Tyler Trent Ochoa, Introduction: Tiger Woods and the First Amendment, 22 WhitTier L. ReV. 381 (2000); Linda J. Stack, Note, White v. Samsung Electronics America, Inc.'s Expansion of the Right of Publicity: Enriching Celebrities at the Expense of Free Speech, 89 Nw. U. L. REv. 1189 (1995). But see Zacchini v. Scripps-Howard Broad. Co., 433 U.S. 562 (1977) (finding no First Amendment obstacle to a right of publicity claim against a news broadcast that captured the entirety of plaintiff's fifteen-second human cannonball act).

There is a considerable literature discussing the First Amendment and the right of publicity. See, e.g., Barbara A. Burnett, The Property Right of Publicity and the First Amendment: Popular Culture and the Commercial Persona, 3 Hofstra PROP. L.J. 171 (1990); Michael E. Hartmann \& Daniel R. Kelly, Parody (of Celebrities, in Advertising), Parity (Between Advertising and Other Types of Commercial Speech), and (the Property Right of) Publicity, 17 Hastings Comm. \& EnT. L.J. 633 (1995); Kaplan, supra note 180; Kwall, supra note 94; Samuelson, supra note 127; Volokh, supra note 76; Wilde, supra note 180; Alicia M. Hunt, Comment, Everyone Wants To Be a Star: Extensive Publicity Rights for Noncelebrities Unduly Restrict Commercial Speech, 95 Nw. U. L. REV. 1605 (2001); Sargent, supra note 180.

272. Among the numerous discussions of copyright and the First Amendment, most suggest that courts don't take the problem seriously enough. See, e.g., Floyd Abrams, First Amendment and Copyright, 35 J. COPYRIGHT SOC'Y 1 (1987); Robert C. Denicola, Copyright and Free Speech: Constitutional Limitations on the Protection of Expression, 67 CAL. L. Rev. 283 (1979); Charles C. Goetsch, Parody as Free Speech-The Replacement of the Fair Use Doctrine by First Amendment Protection, 3 W. New Eng. L. ReV. 39 (1980); Paul Goldstein, Copyright and the First Amendment, 70 Colum. L. REv. 983 (1970); Lemley \& Volokh, supra note 180; Neil Weinstock Netanel, Locating Copyright Within the First Amendment Skein, 54 StAN. L. ReV. 1 (2001); Melville B. Nimmer, Does Copyright Abridge the First Amendment Guarantees of Free Speech and Press?, 17 UCLA L. REV. 1180 (1970); Hon. James L. Oakes, Copyrights and Copyremedies: Unfair Use and Injunctions, 18 Hofstra L. Rev. 983 (1990); L. Ray Patterson, Free Speech, Copyright, and Fair Use, 40 Vand. L. Rev. 1 (1987); David E. Shipley, Conflicts Between Copyright and the First Amendment After Harper \& Row, Publishers v. Nation Enterprises, 1986 BYU L. REV. 983; Alfred C. Yen, A First Amendment Perspective on the Idea/Expression Dichotomy and Copyright in a Work's "Total Concept and Feel," 38 EMORY L.J. 393 (1989); Geri J. Yonover, The Precarious Balance: Moral Rights, Parody, and Fair Use, 14 CARDOZO ARTS \& ENT. L.J. 79 (1996); Mel Marquis, Comment, Fair Use of the First Amendment: Parody and Its Protections, 8 Seton Hall Const. L.J. 123 (1997); cf. Neil Weinstock Netanel, Copyright and a Democratic Civil Society, 106 YALE L.J. 283, 296-97 (1996) (offering speech-related justifications for limited copyright protection); Diane Leenheer Zimmerman, Information as Speech, Information as Goods: Some Thoughts on Marketplaces and the Bill of Rights, 33 WM. \& MARY L. REV. 665, 666-67 (1992) (suggesting that if anything commentators understate the problems caused by the conflict between copyright law and the First Amendment). 
from ever arising. ${ }^{273}$ We worry that if courts draw on copyright rather than trademark analogies in understanding the right of publicity, one unintended byproduct of that reliance will be to let First Amendment limits on the right of publicity fall by the wayside as well. Arguably that was the effect of the Court's analysis in Zacchini v. Scripps Howard Broadcasting Co. ${ }^{274}$ where it repeatedly analogized the purposes of the right of publicity to copyright law in the course of rejecting a television news team's claim to be entitled to broadcast a fifteen-second performance it deemed newsworthy.

\section{CONCLUSION}

Gerard Magliocca claims that the right of publicity "emerge[d] from trademark infringement's shadow." 275 If so, perhaps it is time for the right to return to that shadow. The best justifications for a right of publicity are trademark-based justifications, and trademark law, unlike the right of publicity, has developed a generally coherent set of rules designed to promote those purposes. The overlap isn't complete- there are ways in which trademark rules must be modified to accommodate the particular characteristics of personal identity - but it is sufficiently great that the rights and limitations of trademark law should serve as the baseline for defining and limiting the right of publicity.

273. See, e.g., Eldred v. Ashcroft, 537 U.S. 186 (2003); Harper \& Row, Publishers, Inc. v. Nation Enters., 471 U.S. 539 (1985).

274. 433 U.S. 562, 573, 576 (1977).

275. Gerard N. Magliocca, From Ashes to Fire: Trademark and Copyright in Transition, 82 N.C. L. REV. 1009, 1027 (2004). 